\title{
The Americanization of European higher education and research
}

Citation for published version (APA):

Borghans, L., \& Cörvers, F. (2009). The Americanization of European higher education and research. METEOR, Maastricht University School of Business and Economics. METEOR Research Memorandum No. 051 https://doi.org/10.26481/umamet.2009051

Document status and date:

Published: 01/01/2009

DOI:

10.26481/umamet.2009051

Document Version:

Publisher's PDF, also known as Version of record

\section{Please check the document version of this publication:}

- A submitted manuscript is the version of the article upon submission and before peer-review. There can be important differences between the submitted version and the official published version of record.

People interested in the research are advised to contact the author for the final version of the publication, or visit the DOI to the publisher's website.

- The final author version and the galley proof are versions of the publication after peer review.

- The final published version features the final layout of the paper including the volume, issue and page numbers.

Link to publication

\footnotetext{
General rights Owners
rights.

- You may freely distribute the URL identifying the publication in the public portal. please follow below link for the End User Agreement:

www.umlib.nl/taverne-license

Take down policy

If you believe that this document breaches copyright please contact us at:

repository@maastrichtuniversity.nl

providing details and we will investigate your claim
}

Copyright and moral rights for the publications made accessible in the public portal are retained by the authors and/or other copyright owners and it is a condition of accessing publications that users recognise and abide by the legal requirements associated with these

- Users may download and print one copy of any publication from the public portal for the purpose of private study or research.

- You may not further distribute the material or use it for any profit-making activity or commercial gain

If the publication is distributed under the terms of Article $25 \mathrm{fa}$ of the Dutch Copyright Act, indicated by the "Taverne" license above, 


\section{Maastricht University}

Lex Borghans, Frank Cörvers

The Americanization of European Higher Education and Research

RM/09/051

\section{METEOR}

Maastricht University School of Business and Economics

Masstricht Research School of Economics

of Technology and Organization

PO. Box 616

NL-6200 MD Maastricht

The Netherlands 


\section{Abstract}

\section{The Americanization of European Higher Education and Research ${ }^{* *}$}

Over the past two decades there has been a substantial increase in the mobility of students in Europe, while also research has become much more internationally oriented. In this paper we document changes in the structure of research and higher education in Europe and investigate potential explanations for the strong increase in its international orientation. While higher education started to grow substantially around 1960, only a few decades later, research and higher education transformed gradually to the American standard. Decreased communication costs are likely causes for this trend. This transformation is most clearly revealed in the change of language used in research from the national language, Latin, German and French to English. Smaller language areas made this transformation earlier while there are also clear timing differences between research fields. Sciences and medicine tend to switch to English first, followed by economics and social sciences, while for law and arts only the first signs of such a transformation are currently observed. This suggests that returns to scale and the transferability of research results are important influences in the decision to adopt the international standard.

JEL classfication: I21, I23, A22, A23, O15

Keywords: Higher education and research, educational expansion, migration, economic development

Lex Borghans

Department of Economics and ROA

Maastricht University

P.O. Box 616

6200 MD Maastricht

The Netherlands

lex.borghans@maastrichtuniversity.nl
Frank Cörvers

ROA

Maastricht University

P.O. Box 616

6200 MD Maastricht

The Netherlands

frank.corvers@maastrichtuniversity.nl

\footnotetext{
** We thank Daniëlle Claassens and Jesper van Thor for their statistical assistance. We benefited from the comments of Charles Clotfelter and Hugo Sonnenschein and the participants of the NBER conferences September 2007 in Cambridge MA and October 2008 in Woodstock, Vermont on earlier versions of this paper.
} 


\section{Introduction}

Over the past two decades there has been a substantial increase in the mobility of students in Europe, while also research has become much more internationally oriented. Student mobility has increased between European countries as well as between Europe, the United States and the rest of the world. This seems to hold at bachelor, master and $\mathrm{PhD}$ level. Compared to the past, European researchers publish more in foreign journals, and there is more international travel, more migration and a strong increase in international cooperation in research. These trends have strong implications for international cooperation and competition in higher education and research.

The aim of this paper is to document changes in the structure of research and higher education in Europe and to investigate potential explanations for the strong increase in its international orientation. The theoretical perspective we take is that the decision to study or to do research in either the home country market or the international market depends on cost and benefits, determined by the size of the market, communication costs, the transferability of knowledge between countries and financial regulations. We argue that several dimensions of this trade-off have shifted in favor of international cooperation: cheaper travel possibilities, European integration, and the use of email and internet. A shift of the priorities in research from discussing and analyzing national policies towards measuring scientific output in international journals could also have stimulated this transition. An increase in the size of the home research market would have an opposite effect. The convergence of country specific habits and institutions towards the global (US) standards has further facilitated the internationalization of research and higher education in Europe.

Using a variety of indicators we show the changes in the structure of higher education and research in Europe. While higher education started to grow substantially around 1960, only a few decades later, research and higher education transformed gradually to the American standard. Decreased communication costs are likely causes for this trend. This transformation is most clearly revealed in the change of language used in research from the national language, Latin, German and French to English. Smaller language areas made this transformation earlier while there are also clear timing differences between research fields. Sciences and medicine tend to switch to English first, followed by economics and social sciences, while for law and arts 
only the first signs of such a transformation are currently observed. This suggests that returns to scale and the transferability of research results are important influences in the decision to adopt the international standard.

To analyze the developments in European higher education and research, the paper compares the developments in research in several European countries in different research areas using long time series. To illustrate some trends in more detail, particular attention will be paid to both the case of economics research and the case of the Netherlands. The developments in economics research and the Netherlands may serve as good examples of what has been or will be happening in other fields across different European countries.

Drèze and Esteban (2007) show that the US outperforms Europe in economics research by a factor of the order three, and conclude that the Lisbon goal set by the European Union, to become the most dynamic and competitive economy in the world, is out of sight. Cardoso and Zimmermann (2008) find that the quality of research by PhDs from US universities is better than the research of European PhDs. ${ }^{1}$ The contribution of this paper is that we take another perspective on the comparison between Europe and the US. Our paper documents the transformation of European higher education and research not just as a change in quality, but in the first place as a change in the nature of the research performed in Europe. We include a theoretical exposition to explain the decision to adopt the American standard in research. This framework explains why the adoption of the superior American standard goes faster in some countries than in others. We argue that it is important to take account of the costs of adopting the American standard to explain how countries perform. Costs as well as benefits of the Americanization of European higher education and research seem to be to a large extent related to the acceptance of English as the lingua franca and to the specific content of what is taught and investigated. We argue that Drèze and Esteban (2007) as well as previous empirical studies in this area pay much attention to the benefits of publishing in the English language in American journals, and ignore or underestimate the productive value of publishing in the home language on European topics.

The remainder of this paper is structured as follows. In section 2 we explain

\footnotetext{
${ }^{1}$ Other papers on evaluating the performance of European and US economics research are e.g. Amir and Knauf (2008), Coupé (2003), Frey and Eichenberger (1993), Kirman and Dahl (1994), Neary et al. (2003), Portes (1987). However, notice that economists typically analyze their own discipline and tend to generalize their results to draw conclusions on the overall position of Europe vis-à-vis the US.
} 
our theoretical framework. Section 3 provides data about the development of higher education in Europe and the US. Section 4 describes the changes that have been taken place in the Dutch higher education and research system during the last few decades, with focus on economics. Section 5 deals with changes in the language used in research as an indicator of change of the structure of higher education and research in Europe. Section 6 concludes.

\section{Theory of internationalization}

Higher education and research is not a homogeneous good. Different countries teach other things in science, economics or law, and the aims and focus of research can be rather different across countries. One important dimension of the differences is whether a country's higher education and research system builds on national structures and traditions, or adopts and perhaps interferes with international standards. This implies that universities/researchers/students can decide to join the national research discussion or to join the international discussion. The value of each choice depends on the quality of the research, its relevance to the country concerned and the costs of research. For national oriented research this value equals:

$V_{\text {nat }}=v_{q} Q(n)+v_{r} R-k$

In which $Q(n)$ is the quality of the research and $n$ the size of the research community. The quality depends on the size of the community. $R$ represents the relevance of research and $k$ the costs. $v_{q}$ and $v_{r}$ are the weights attached to quality and relevance. For international oriented research the value equals:

$V_{\text {int }}=v_{q} Q(N)+v_{r} \tau R-K$

$N$ is the size of the international research community. If the benefits from research are subject to returns to scale, a researcher who joins the international debate profits from a larger peer group. These benefits are counterbalanced however by a reduced benefit of the research findings for the situation in the home country and higher communication costs. $\tau$ represents the degree of transferability of research findings 
to the national situation ( $0 \leq \tau \leq 1)$. The transferability might depend on the research area. In some fields the relevance of research will not depend on the country that is investigated, while for other fields of research this might be very country specific. Furthermore, international oriented research might incur higher costs, due to higher travel and communication costs. These costs are indicated by $K(K>k)$.

The trade-off between national or international research might also be influenced by the value attached to quality versus relevance. A researcher will choose to join the international research community when $V_{\text {int }}>V_{\text {nat }}$. Given the difference in quality of research but also the costs in the international versus the national context, the threshold level of transferability can be calculated for which researchers are indifferent between joining the national or the international debate:

$$
\bar{\tau}=1-\frac{v_{q}}{v_{r}} \frac{Q(N)-Q(n)}{R}+\frac{K-k}{R}
$$

If the actual transferability exceeds this threshold, the international debate will be chosen. So if the transferability of research findings increases, the costs of international research decrease or the scale effects increase, researchers participating in the national debate will switch to the international debate when this threshold is reached. Also a change in the valuation of quality versus relevance might lead to this change. At the point of transition, the value of research will change only gradually. The move from the national to the international debate will affect quality and relevance substantially, though. In Figure 1 we show for certain parameters of this model what would happen to the quality and relevance of research per unit of costs when transferability increases (1a) and the costs of international research decrease (1b). Panel a shows that the transition from the national to the international debate is associated with a decrease in relevance and an increase in quality. Once the transition is made, a further increase in transferability will not affect the research quality but will increase relevance. When costs of international research are reduced (panel b), a similar shift towards higher quality and lower relevance is observed. A further reduction of the costs of international research will benefit both quality and relevance per unit costs.

If the size of the market, communication costs, transferability and incentives 
determine the choice for either national or international oriented research, the following predictions can be made:

\section{Size of the market}

The growth of higher education in Europe and the process of European integration will shift the attention of researchers towards the European market. This will imply a decrease of the importance of research aimed at specific European countries, but would also reduce the focus on international research.

\section{Communication cost}

There are many reasons to assume that communication costs are decreasing. Travel is cheaper, internet and email provided important tools for long distance communication between researchers while European integration (the use of English and the introduction of the BA-MA system) improved comparability and therefore facilitated communication.

\section{Transferability}

Differences in transferability of research in the first place might predict differences between research fields. For sciences it will be relatively easily to join one international research discussion, while e.g. for literature and law national differences might be too large to allow for international cooperation, because of the importance of distinctive national institutions, cultural traditions and history. Economics and social sciences will be an intermediate case. Although these disciplines apply general theories, specific circumstances and institutions within countries might affect the relevance of certain research questions and limit international comparability.

\section{Finance}

In many European countries there is a trend towards subsidies based on research output, e.g. the number of publications, number of diplomas and number of $\mathrm{PhDs}$. Such financial incentives will also affect decisions with respect to research, although the direction of these influences is sometimes difficult to predict.

To facilitate cooperation between researchers in either the national or the international research discussion, it is likely that conventions will be adjusted towards 
a common standard. The most obvious case of this is the language, but one could also think about a standardization of other aspects to facilitate comparability.

Standardization of diplomas, both in terms of names and content is such an example. The adoption of the BA-MA structure in place of historically unique European degrees can be interpreted in this way, but also the use of terminology such as assistant professor, associate professor and full professor and the role of a $\mathrm{PhD}$ thesis could be affected by changes in the values of the research community.

In this paper we will therefore look at trends in the language used in research, the nationality of researchers who publish in national journals, the country of origin of research that is cited, but also at the age at which the $\mathrm{PhD}$ thesis is typically finished.

\section{Developments in higher education}

Like in the USA many of the richer European countries faced a rapid increase of participation in higher education in the $60 \mathrm{~s} .{ }^{2}$ Universities were transformed from small elite schools to mass universities. ${ }^{3}$ Figure 2 shows the increase in participation in higher education in Western European countries and the US from 1970 onwards. There is a huge difference in gross enrollment ratios between the US and Western Europe. This does partly reflect differences in the educational system, such as a strong emphasis on a solid system of intermediate vocational education in many European countries. Between 1970 and 1975 gross enrollment in higher education in Western Europe and the US increased by 5 to 10 percent points. The trend in gross enrollment was almost flat between 1975 and 1985 and started to accelerate around 1985. The US achieved a maximum of approximately 80 percent gross enrollment from 1991 onwards (with the exception of 1999-2001). The Scandinavian countries more or less caught up with the US in recent years. Other countries still have gross enrollment ratios that are 15 to 30 percent points lower than the US.

The rising participation in higher education in Western Europe may be one of

\footnotetext{
${ }^{2}$ See Eurydice (2000) for the developments in higher education since the 1960s in 18 Western European countries. See for the development of the highest level of educational attainment in the US from 1940 to 2007 Figures 3 and 4 in the Digest of Education Statistics: 2007 of the National Center for Education Statistics (2008).

${ }^{3}$ Windolf (1997) discusses the educational expansion in Germany, the US, Japan and some other European countries between 1870 and 1990. To explain the expansion of higher education he refers to human capital theory and the needs of society, and theories from educational sociology that are based on competition for status between individuals or between social groups. He also discusses the relevance of the increasing enrollment of women for educational expansion.
} 
the explanations for the rising trend of European students going to the US. This is indeed confirmed by Figure 3. The enrollment of Western European students slowly increased between 1949 and 1970, then dropped till 1975, and accelerated from 1975 onwards. Around 1993 the growth of the number of Western European students in the US leveled off, to stabilize at the level of about 50.000 students. After 2000 the enrollment of students coming from Western Europe to study in the US dropped slightly, probably due to stricter regulations in the US after 9/11. For students in the rest of Europe (including Central and Eastern Europe) Figure 3 shows that outbound mobility in absolute numbers was rather low until the second half of the 80s. After then outbound mobility sharply increased, to reach a maximum of more than 30.000 students in 2002. During the last two years of the time series the outbound mobility from Europe as a whole to the US decreased. For the total number of foreign students going to the US the decrease started in 2004.

One could suppose that the rising number of European students going to the US can be explained by rising 'globalization'. Figure 4 shows that this can only be partly true. The figure shows outbound mobility of Western European students to the US as a percentage of the number of students enrolled in higher education in 10 different Western European countries. For most countries the percentage of outbound mobility is relatively high in 1970, even higher than in 2006, the last year of the time series. With 1975 as the reference year, all countries show up an upturn, but sooner or later outbound mobility starts to fall again for each country. Thus there is no clear upward trend of outbound mobility since 1970. Almost all countries show a downward trend during the last 5 to 10 years. For the UK the share started to fall in 1988, for Norway even in 1985. The percentages remain relatively high for the Scandinavian countries till the end of the time series. Italy, and to a lesser extent Spain, typically have low shares of outbound mobility to the US.

It may be argued that EU inner mobility flows compensated for the decline in outbound mobility from Western Europe to the US. On the one hand, the inner EU programs, such as the Erasmus program, indeed seem to be expanding over time (European Commission, 2008). ${ }^{4}$ On the other hand, Figure 5 suggests that outbound

\footnotetext{
${ }^{4}$ One has to notice that mobility in the European Union is typically so called 'horizontal mobility'. In programs like the Erasmus program students spend a substantial time (from 3 to 12 months) at another European institution of higher education, having all the academic credits recognized by and transferred to the home institution. As is remarked by Spinelli (2005), students in the US practice 'vertical
} 
mobility as the percentage of home enrollment declined after 2002 in all countries of our sample. An explanation for this difference is that enrollment data from the Unesco does not include mobility flows of students collecting credits in another European country, nor student exchange programs within the European Union. From Figure 5, we can conclude that Norway, Austria and Sweden have the highest numbers of students enrolled in foreign countries relative to home enrollment.

A higher students' participation in inner EU programs fits into the ambition of the European Union of establishing a European Higher Education Area (EHEA) by 2010, which has been agreed upon in the Bologna Declaration of June 1999. This agreement was originally signed by the education ministers of 29 European countries and developed into a major reform encompassing 45 countries. It has put in motion a series of new agreements and reforms (the 'Bologna Process', see European Commission, 2007 and NAFSA, 2007) to make European higher education more compatible and attractive for students in Europe and from other continents. The European Union considers these reforms as a requirement to match the performance of the best performing systems in the world, notably the United States and Asia. The objectives of the Bologna Declaration include the adoption of a system of easily readable and comparable degrees, the adoption of a system essentially based on two main cycles, the establishment of a system of credits, the promotion of mobility, the promotion of European cooperation in quality assurance, the promotion of the European dimension in higher education.

For stimulating transatlantic mobility in particular the adoption of a system based on two main cycles, undergraduate and graduate, is important, ${ }^{5}$ as well as the establishment of a system of credits (such as the ECTS). Before the Bologna Process, the higher education system of continental European countries generally had one integrated tier only, leading to the title necessary for entering $\mathrm{PhD}$ courses. In the Bologna Declaration it has been agreed that the bachelor degree awarded after the first cycle, lasting a minimum of three years, shall become relevant on the European labor market as an appropriate level of qualification. Access to the second cycle requires

\footnotetext{
mobility,' i.e. they mainly pursue a graduate degree at a different institution from where they have received their undergraduate degree.

${ }^{5}$ For example, Spinelli (2005) refers to difficulties for US administrators to understand the level of European students who had not completely finished their European degree in the one-tier system. There were problems even for students who graduated from a five-year integrated course (i.e. master's level), to whom U.S. administrators generally offered admission to master instead of $\mathrm{PhD}$ courses since they were holding one degree only.
} 
successful completion of first cycle studies. The second cycle leads to the master's degree. Initially only two cycles were mentioned, equivalent to undergraduate and graduate. Later the doctoral (or doctorate) degree was introduced as the third cycle. ${ }^{6}$ Although European countries are committed to convert their existing higher education programs to a three-year bachelor's and two-year master's, in reality there is a large variation between countries in the length of the cycles and in the intermediate credentials traditionally offered (Adelman, 2009).

Figure 6 shows the percentage of outbound students per country who are going to the US for the period 1999-2006. The percentages are relatively high for the UK and Sweden, with about one quarter to one third of their outbound students enrolling in the US. Italy and Austria have low shares of students enrolling in the US. The shares dropped relatively much for students from Norway and Germany between 1999 and 2006. On average the market share of the US in total outbound mobility of the 10 Western European countries in our sample was approximately 15\% in this period. We can conclude that the US has not become less attractive for European students that want to study abroad, either within or outside Europe. However, since enrollment of Western European students outside their own country seems to have decreased during the last years or more for many countries, this also holds for the number of Western European students studying in the US. This development may be caused by the increasing popularity of mobility programs like the Erasmus program that stimulate European students to study in another European country, which is not counted as enrollment in the Unesco figures.

Figure 7 depicts the number of US students abroad between 1955 and 2003. Total study abroad of Americans increased between 1955 and 1990, then dropped slightly and started to accelerate after 1992. The share of Europe in study abroad decreased due to the rise of Asian countries. US students hardly go to European countries outside Western Europe. Whereas the number of Western European students in the US accelerated from 1975 onwards, the number of US students in Western Europe only started to grow strongly after 1992, thus much later.

Table 1 shows the number of US students relative to the number of students enrolled in the country they go to. The table does not reveal a clear general trend for all countries between 1970 and 1996. After 1996 there is an upward trend. The UK is

\footnotetext{
${ }^{6}$ See Witte (2006) for a detailed account and analysis of the evolution of the three cycles.
} 
the most attractive country for American students because of the English language. Remarkably, during recent years Austria, Spain and Italy have become the most popular countries after the UK. Obviously these countries succeed in attracting American students by reforming their university system in line with the Bologna Process and by offering good quality courses in English. Moreover, the relatively large communities with a Spanish or Italian family background in the US may induce American students from these communities to study in Spain or Italy. So while in the 80s the number of European students that went to the USA increased - in line with the increased participation in higher education in Europe - only recently European universities became more open to foreign students.

\section{Americanization: The case of the Netherlands}

To illustrate the outcomes of the theoretical model in more detail, we discuss the developments in higher education and research for the case of the Netherlands, and where useful refer to other European countries or the US. Figures 8 and 9 summarize some basic facts about the size and growth of higher education in the Netherlands. Figure 8 depicts the growth in the country's two major higher education sectors, distinguishing the number of students in universities from students in professional higher education (Hoger Beroeps Onderwijs, or HBO). Dutch universities are always research universities, and incorporate business schools, law schools and medical schools. HBO institutions are typically not engaged in research, and teach professional skills, e.g. for nurses, teachers, therapists, accountants and practically oriented engineers. The strongest increase in the number of students is in the 60s, but the number keeps increasing until the early 80s. From the 80s on the growth in participation at the universities stagnates, while participation at the professional colleges continues to grow. Fluctuations in participation rates for universities from the 80s onward mainly reflect new regulations that aim at a reduction of the years spent at university.

Figure 9 focuses on universities and compares the enrollments with the size of the faculty. In line with the growth of the number of students also the number of teachers and researchers grows. The growth rate of faculty is about $50 \%$ of the growth rate in student population, implying an increase in the student-faculty ratio from 3 to 7 between 1960 and 1990. The break between 1990 and 1991 is due to a change in 
definition.

The internationalization of Dutch higher education is evident in the growing numbers of Dutch university students going to the US to study and American students going the other way, to study in the Netherlands. Figure 10 shows the participation of Dutch students in American higher education. For comparison, the corresponding trend is shown for German participation, which, as shown in Figure 3 above, is representative of Western Europe as a whole. For both countries the start of this growth in the early 60s coincided with the growth of higher education in Europe. Around 1975 there was a sharp decline in the participation of Dutch and German students at US universities, but after 1975 this trend recovered. From 1975 until 1992 the participation of Dutch students in the USA grew faster than the German participation, after which Dutch enrollment fell. The same happened to German participation after 2001, as it did in many other Western European countries during the last decade, as has been revealed in the discussion of Figures 3 and 4.

Initially only a very small fraction of foreign students in the Netherlands came from the US, but this changed in the 90s when some universities started to provide courses in English in some fields. Figure 11 shows the increase of US students in the Netherlands in those years. Between 1995 and 1998 the participation of US students more than doubled and has continued to increase since then. Participation of Dutch students in the USA increased much earlier, and was related to the rise of higher education in the Netherlands. Similar trends can be seen for other Western European countries (compare Figure 4 and Table 1 of the previous section). Significantly, the magnitudes of these mobility flows differ by discipline, with disciplines such as law being more nationally oriented than others. This fact is clearly demonstrated in Figure 12, which shows that the percentages of foreign students are lowest in fields like health care, law, education and language and culture. The more science-oriented studies and economics display a much higher influx of foreign students. Finally, note that the total number of foreign students enrolled in Dutch higher education has been increasing since 2004, as has the percentage of US students (see Table 1).

“Americanization” of Dutch higher education is more starkly evident in the transformation that has taken place in the very degrees, titles, and objectives that define academic institutions. Table 2 describes several key characteristics of Dutch universities in 1980 and 2008. The focus is on economics. In 1980 a degree program in economics nominally required 5 years, but in fact most students spent much as 
much as 6 to 10 years to complete their study. The diploma was called "drs.” and was regarded as equivalent to a MA diploma. In 1982 the nominal duration was reduced to 4 years, although the diploma remained officially unchanged. Furthermore, measures were taken to reduce the time spent at university to a maximum of 6 years. Later further measures were taken to reduce the length of stay. In 2002 - following the Bologna Declaration of 1999 - the structure was changed into a BA-MA-structure, with 3 years of bachelor and 1 (sometimes 2) years of MA.

In the 80 s it was very common for members of the faculty not to have a $\mathrm{PhD}$. Some wrote a "proefschrift" (PhD thesis) as a member of the faculty. Some of them used this thesis as an opportunity to bring together all their research at the end of their career as a magnus opus. Others never wrote a $\mathrm{PhD}$ thesis, but could nevertheless become full professor. Famous professors in economics at that time were often involved in the national political discussion about economics. Many were affiliated with a political party and joined national committees advising the Dutch government about economic policy. Gradually this situation shifted. Obtaining a $\mathrm{PhD}$ became a prerequisite to become assistant professor, and an official $\mathrm{PhD}$ program was implemented (aio). Initially, aio's just had to write their thesis, but gradually course work was introduced in these programs. Joining the national debate and publishing in national journals became less important while success in international publications gradually became the measure of success.

Initially there was not one European system for higher education. Like the Netherlands, most countries in Europe had their own specific characteristics. Germany had and has a 'habilitation', a kind of second thesis after $\mathrm{PhD}$, required to become full professor. France distinguishes many different diplomas for different levels obtained in higher education, and has a distinction between universities that focus mainly on teaching, and écoles superieure. In international comparisons such differences are not always acknowledged, for several reasons. First, international communication about higher education is clearly affected by selection bias: those who go to international conferences prefer the international system and therefore behave most of the time in accordance with the American standard and tend to describe their home situation by using the American terminology. Secondly, for international statistics, degrees are translated to facilitate comparison, hiding the obvious differences between degrees in different countries. Thirdly, when norms change about what is good research, there is a tendency to judge research in the past using these 
new norms. Consequently researchers who do not publish in international journals are easily considered to be lazy: differences in the system are therefore regarded as a lack of appropriate incentives.

To show how the PhD has changed in the Netherlands, we constructed a time series on doctoral dissertations defended at Dutch universities before 1990 using information from the library of Maastricht University that holds all these titles. Figure 13 compares the number of PhDs awarded with total university enrollment. The figure makes clear that these two indicators follow very different patterns. Initially, writing a $\mathrm{PhD}$ thesis was not a requisite for faculty, as shown in Table 2. There were many full professors who did not obtain a $\mathrm{PhD}$ and some wrote their $\mathrm{PhD}$ later in their career as a summary of all their main research. Only in the mid-seventies did this start to change and nowadays for most positions as an assistant professor a $\mathrm{PhD}$ is required.

Figure 14 shows the average age of $\mathrm{PhDs}$ by discipline for the doctoral dissertations in our library sample from 1970 till 1995. As has been argued before, we expected that the age at which candidates received their PhDs would fall over time due to the transition of the Dutch to the Anglo-American system. After 1980 the average age did indeed fall for all disciplines except arts. The decrease was most prominent for science, and for economics. In these disciplines the transition to the Anglo-American system may have been most prominent.

\section{Importance of language for research}

One way to illustrate the increasing dominance of Anglo-American academic research is to look at the language in which Continental European researchers are publishing. Nowadays it is common in many research fields and countries to publish in English. However, for some fields, like law and national history, this seems to be less relevant due to a lack of international academic audience that is interested in country-oriented research. In contrast, for areas like physics, chemistry and medicine the international academic community is more or less dealing with the same questions everywhere. Therefore in these areas the interest to understand each other and to communicate in the same language is much bigger. Moreover, due to globalization and converging institutions - think of financial markets, international law, the end of communism in many countries, but also the higher education system - societies may have become more similar over time. Therefore the interest in sharing the knowledge that emerges 
from research is probably increasing. Communicating in one instead of different languages makes it easier to ensure that research output gets feedback from others all over the world, and that new knowledge will be generalized and used for practice.

\subsection{Doctoral dissertations}

\section{International}

To illustrate the growing dominance of the English language in academic research on the European continent we use data of the foreign doctoral dissertation database of the Center for Research Libraries (CRL) in Chicago. ${ }^{7}$ For nine Continental European countries in the database we analyzed to what extent the doctoral dissertation have been written either in the home language or in English, and how the share of dissertations in the home language has evolved over the last hundred years. The CLRcollection includes doctoral dissertations submitted to institutions outside the U.S. and Canada. A list of these institutions is available at the CLR-website (see footnote 5). The subjects of the dissertations are very mixed, but the database contains no variables to categorize the dissertations by discipline. We did some provisional analyses on recent years of databases from French, Danish, German and Austrian national libraries to check our results. We found that the CLR-data are reasonably well in line with those in other national data sources.

Figure 15 presents by country the percentages of home language dissertations in the total of home and English language dissertations. The percentages are averages for 10-years periods between 1908 and 2007 (see the Annex). The figure shows that in many Continental European countries the development of increasingly writing dissertations in English started as far back as the beginning of the previous century. This holds in particular for the Scandinavian countries. The Netherlands had a somewhat slower start, but caught up with these countries. Italy seems to follow the Netherlands till the 1960s, but then remained more or less constant. During the last 10 to 20 years, PhDs in Spain and Austria increasingly wrote their thesis in English. In

\footnotetext{
${ }^{7}$ The CRL is a consortium of North American universities, colleges and independent research libraries. The consortium acquires and preserves newspapers, journals, documents, archives and other traditional and digital resources for research and teaching. These resources are then made available to member institutions cooperatively, through interlibrary loan and electronic delivery. The CRL-website for foreign dissertations is: http://www.crl.edu/content.asp?l1=5\&l2=23\&l3=44\&l4=25
} 
Germany this process seems to have started up only recently. Based upon the CRLdatabase, $5 \%$ of the doctoral dissertations in Germany were written in English by 1998-2007.

In France there is only the barest indication of movement toward English. ${ }^{8}$ It seems that countries that are part of big language areas (i.e. French, German and Spanish) have small incentives to switch to publishing in English. Moreover, France is known for its language policies in many different areas of life. ${ }^{9}$ As has been argued in Section 2 of this paper, the costs of switching to publishing in English are the largest for countries that are part of big language areas due to economies of scale. However, Drèze and Estevan (2007) conclude that the big four Continental countries (France, Germany, Italy and Spain) should accept English as the lingua franca to catch up in performance in economics research with the UK and the small countries in Western Europe. Although their paper is measuring the performance in economics research only, their conclusion may hold for other fields as well.

\section{The Netherlands}

Figure 16 shows the language that was used in the doctoral dissertations in our sample of dissertations in the Maastricht University library system. We distinguished among the five languages that appear to have a substantial frequency: Latin, Dutch, German, French and English. The figure shows the cumulative shares of these languages. Until about the 1850s Latin was the main language in doctoral dissertations at Dutch universities. After the 1850s this changed very rapidly, and Dutch became the main language. Also the importance of German and later on French increased. The share of English dissertations began to increase only after the First World War. This share started to increase very rapidly in the 1960s. Latin was still used in a number of Dutch doctoral dissertations till the 1960s.

The use of English in doctoral dissertations differs very much between disciplines, as Figures 17 reveals. Science and medicine have the largest share of doctoral dissertations in English, followed by economics and social sciences. In law

\footnotetext{
${ }^{8}$ From the extensive 'Système universitaire de documentation' of French academic libraries we found that till 1997 almost all doctoral dissertations in France had been written in French. In 2002 1\% of the dissertations were written in French and in 2007 this percentage increased to 3\%.

${ }^{9}$ For example the use of French is required by law in commercial and workplace communications (Toubon Law). However, we do not know exactly how French governmental language policies can affect the use of language in academic publications.
} 
the use of English is even smaller than in arts. The figure also reveals that the share of dissertations in English increased very much in medicine. Substantial increases are also evident for science, economics and social sciences. The increase for arts and law was only moderate.

\subsection{Economics journals}

\section{International}

The switch to the use of the English language can also be analyzed for academic journals. We looked at the publishing language of many Continental European and Anglo-American economics journals since the emergence of the first academic journals in economics around 1850. We follow these journals from the year of foundation, and noted when they switched from their home language to English. The selection of economics journals in different Continental European and AngloAmerican countries is based on the overview by Gonçalo L. Fonseca. The list of selected journals has been published on the website 'Economics Journals: A Chronological Account'. ${ }^{10}$ Only journals founded before 1990 were included on this website. We checked the year of foundation and the year when the journal stopped publishing with other data sources.

For none of the twelve Continental European countries in our dataset English is a native language. Countries can have more than one national languages (like German and French in Switzerland), and obviously the same language can be spoken in different countries. Journals may start in English from the foundation year (like an Italian and two Soviet journals), or switch to English at a later stage (see the Annex for detailed data). Information on the year of switching to English was drawn from data sources such as home pages of journals, national libraries, and EconLit. Journals need to publish all regular articles (i.e. excluding book reviews, etc.) in English to be considered as an English language journal. The first year in which this happens is noted as the transition year (this can also be after 1990).

\footnotetext{
${ }^{10} \mathrm{http}: / /$ cepa.newschool.edu/het/essays/journal.htm . We selected the period from 1850 onwards, when the first academic economics journals emerged. We excluded the light and news oriented journals, or journals not principally dedicated to economics, which are all marked as such on the website.
} 
In Figure 18 the emergence of Continental European economics journals and their language use is presented. The total number of journals has gradually increased since 1844. After World War II did the number of journals suddenly increase, and the first English language journal on the Continent was published (the Italian Banca nazionale del lavoro quarterly review). This journal was a new journal, as were also two Soviet journals founded in 1958 and 1964. The first old economics journal that switched to English was the Swedish Ekonomisk Tidskrift in 1964. In the same year it also changed its name into Scandinavian Journal of Economics. Starting from the first half of the 1990s the use of German (in journals from Germany, Austria and Switzerland) and other languages (Italian, Spanish) seriously declined. By 2001 only four German and two other language journals were left. Many economics journals in these languages switched to English or disappeared. On the contrary, all French language journals from France as well as from Belgium and Switzerland, kept publishing in French. It has to be noticed that some French journals are bilingual, publishing French as well as English articles. These journals are not counted as English language journals in our dataset. Even taking this strict definition the English language journals on the European continent outnumber the French language journals during the last few years (13 versus 12 in the year 2001).

Figure 19 shows the development of the number of English language economics journals in Anglo-American countries since 1859 until 1990. For some years there was only one serious academic economics journal according to our source (the British Macmillan's Magazine, 1859-1907; see the Annex). In 1886 the first US journal was founded (Quarterly Journal of Economics), and in 1891 the first well known British economics journal emerged (Economic Journal). Only after World War II the US journals began to outnumber the journals in the UK and other English speaking countries (Australia, Canada, South Africa). The first international journal (i.e. without a real home country) was published in 1921. Around 1970 the number of international journals suddenly increased. In 1990 there were 26 international journals, 28 US journals and 14 English journals in the UK and other English speaking countries.

The Netherlands, Austria and Italy 
To show the development in international orientation of economics journals in more detail, we analyzed three general interest journals. These journals are De Economist, founded in 1852 in the Netherlands, the Journal of Economics, founded in 1892 in Austria as the Zeitschrift für Nationalökonomie, and Research in Economics founded in 1947 in Italy as Ricerche Economiche. For these journals we drew information from databases on the internet with respect to the language of articles, the nationality of the authors, and the language of the references to other publications. ${ }^{11}$

Figure 20 shows the decline of the use of the home language in the Netherlands, Austria and Italy. For the Netherlands the decline went rather fast after the beginning of the 70s. Within less than a decade the language switched from Dutch to English. From 1983 onwards no regular articles have been published in Dutch anymore. For Austria, Figure 20 shows that the switch from German to English in the Austrian Journal of Economics started about a decade earlier compared to De Economist. However, it took about two decades to transform the journal from German to English. From 1982 onwards no regular articles have been published in German anymore. In Italy, as in the Netherlands, the switch from Italian to English was accomplished in about a decade. Figure 26 shows that the switch for Research in Economics took place later than for De Economist in the Netherlands and the Journal of Economics in Austria. From 1993 onwards no regular articles in this journal have been published in Italian anymore.

The language change in De Economist certainly coincided with the nationality of the authors. The decline of the fraction of Dutch authors, however, developed more gradually than the decline of the fraction of articles in Dutch, as is shown in Figure 21. Moreover, the fraction of articles by German or Austrian authors in the Journal of Economics declined rapidly after World War II. The fraction reaches a level below $20 \%$ in the late 80 s and the early 90 s. In recent years the fraction of German and Austrian authors however increased again. Figure 21 also provides information about the nationality of the authors in Research in Economics. Since the 80s the fraction of Italian authors gradually decreased, reaching a level of about $20 \%$ in recent years.

\footnotetext{
${ }^{11}$ For De Economist and the Journal of Economics we used the website of Springer, for Research in Economics we used the Elsevier website for the years after 1996, and the following website for the period from 1960 to 1996: http://www.biblio.liuc.it/essper/schedper/p78.htm
} 
Figure 22 shows the developments in the language of the references in English written papers published in De Economist and the Journal of Economics. The change in international orientation of De Economist had a clear impact on the language of the publications to which was referred to in the articles. In the 1960s between $40 \%$ and $50 \%$ of the references were in the Dutch language. During the last decades this share was less than $10 \%$ for most years. Also for the Journal of Economics the change in international orientation had a clear impact on the fraction of references to publications in the home language. The fraction decreased over years. In particular after 2000 this fraction is very low.

\section{Conclusions}

In this chapter we document the shift of the European research and higher education system from a national to an international - and American - orientation. This gradual process did not start immediately after the expansion of higher education, but developed over time. Smaller countries with smaller language areas were the first to adopt English as a research language and to adjust their system to American standards suggesting that returns to scale are an important factor in the decision to join the international research society. Comparing between fields of study, sciences and medicine turn out to make this change earlier than economics and social sciences, while in arts and law the majority of the work still is focused on the home country. Differences in the transferability of research outcomes may account for these differences.

These trends might imply that mobility of students and researchers in Europe will increase substantially in the years to come. The standards used, the use of English and a focus on American research, go hand in hand. So once these changes start, it becomes increasingly beneficial to continue this process. At the same time, when more researchers join the international society, the scale of the national research communities shrinks, which further stimulates internationalization. When research in Europe becomes more harmonized and more focused on American research, the need for European students to study in the US might be reduced while at the same time the system will become more attractive for students and researchers from outside Europe. Until now the inflow of students from outside Europe is still relatively small, so we can only speculate about the potential size of these developments. Another remaining 
question is whether law and arts will follow other disciplines in their shift towards the American/international standard.

Further progress in the establishment of a European Higher Education Area (EHEA), which is part of the Bologna Process, can create an American-like competitive European standard for higher education, in particular when the European Union succeeds in the full adoption of a system based on two main cycles for undergraduates and graduates with a transparent system of credits. As is noticed by Drèze and Estevan (2007), the introduction of English as the lingua franca of universities, particularly in the big four continental countries, is a prerequisite to increase European competitiveness. Other conditions for increasing its competitiveness (see also Mas-Colell, 2003) are better governance at European universities and concentrating $\mathrm{PhD}$ programs at fewer universities.

In our analysis of student mobility flows between Europe and the US we found the first indications of a declining enrollment of European students in the US, whereas studying abroad in Europe by US students seems to be on the rise. In the long term similar developments could occur for the number of $\mathrm{PhD}$ students and researchers going to the US. Only if international/American standards are adopted in European higher education and research can Europe as a whole become more attractive for students and researchers all over the world, and challenge the US as the number one. 


\section{References}

Adelman, C. (2009), The Bologna Process for U.S. Eyes: Re-learning Higher

Education in the Age of Convergence, Institute for Higher Education Policy,

Washington, DC.

Amir, R. and M. Knauff (2008), Ranking Economics Departments Worldwide on the Basis of PhD Placement, Review of Economics and Statistics, Vol. 90(1), pp. 185-190.

Cardoso, A.R., P. Guimarães and K.F. Zimmermann (2008), Comparing the Early Research Performance of PhD Graduates in Labor Economics in Europe and the USA, IZA Discussion Paper No. 3898, Institute for the Study of Labor, Bonn.

Center for Research Libraries, Catalog of Foreign Doctoral Dissertations Database: $\underline{\text { http://www.crl.edu/content.asp?l1 }=5 \& l 2=23 \& l 3=44 \& l 4=25}$

Coupé, T. (2003), Revealed Performances: Worldwide Rankings of Economists and Economics Departments, 1990-2000, Journal of the European Economic Association, Vol. 1(6), pp. 1309-1345.

Drèze, J.H. and F. Estevan (2007), Research and Higher Education in Economics: Can We Deliver the Lisbon Objectives? Journal of the European Economic Association, Vol. 5 (2-3), pp. 271-304.

European Commission (2007), THE BOLOGNA PROCESS, Towards the European Higher Education Area:

http://ec.europa.eu/education/policies/educ/bologna/bologna_en.html

European Commission (2008), Erasmus - Statistics, Erasmus student and teacher mobility:

http://ec.europa.eu/education/programmes/llp/erasmus/statisti/table1.pdf 
Eurydice (2000), Two Decades of Reform in Higher Education in Europe: 1980 Onwards, Education and Culture Directorate General, European Commission, Brussels.

Fonseca, G.L., Economics Journals: A Chronological Account:

http://cepa.newschool.edu/het/essays/journal.htm

Frey, B. and R. Eichenberger (1993), American and European Economics and Economists, Journal of Economic Perspectives, Vol. 7(4), pp. 185-193.

Institute of International Education, Open Doors 1948-2004, Report on International Educational Exchange: CD-ROM, Sewickley, PA.

Kirman, A. and M. Dahl (1994), Economic Research in Europe, European Economic Review, Vol. 38, pp. 505-522.

Mas-Colell, A. (2003), The European Space of Higher Education: Incentive and Governance Issues, Rivista di Politica Economica, Vol. 93(11-12), pp. 9-27.

NAFSA (2007), The Bologna Process, International Educator Bologna 2007

Supplement:

http://www.nafsa.org/_Document/_/bolognaprocess_ie_supp.pdf

National Center for Education and Statistics (2008), Digest of Education Statistics: 2007, March, Washington DC:

http://nces.ed.gov/programs/digest/d07/index.asp

Nuffic (2008), Internationalization in Education in the Netherlands 2007, The Hague.

Neary, P.J., J.A. Mirrlees and J. Tirole (2003), Evaluating Economics Research in Europe: an Introduction, Journal of the European Economic Association, Vol. 1(6), 1239-1249.

Periodicals Service Company \& Schmidt Periodicals GmbH: http://www.periodicals.com/download.html 
Portes, R. (1987), Economics in Europe, European Economic Review, Vol. 31(6), pp. 1329-1340.

Spinelli, G. (2005), Mobility and Admission of Graduate Students Across the Atlantic: New Challenges with the Bologna Process, IIENetworker Magazine, Spring: http://www.iienetwork.org/?p=Spinelli

Unesco Institute for Statistics, Data for 1970-1996:

http://www.uis.unesco.org/pagesen/ed.htm

Unesco Institute for Statistics, Data for 1999-2006:

http://stats.uis.unesco.org/unesco/tableviewer/document.aspx?ReportId=143

Windolf, P. (1997), Expansion and Structural Change: Higher Education in Germany, United States and Japan 1870 -1990, Westview, Boulder.

Witte, J. K. (2006), Change of Degrees and Degrees of Change: Comparing Adaptations of European Higher Education Systems in the Context of the Bologna Process, Doctoral dissertation, University of Twente, Netherlands. 
Table 1

US students as percentage of enrollment in Western European countries, 1970-2003

\begin{tabular}{lrrrrr}
\hline & $\mathbf{1 9 7 0}$ & $\mathbf{1 9 8 6}$ & $\mathbf{1 9 9 2}$ & $\mathbf{1 9 9 6}$ & $\mathbf{2 0 0 3}$ \\
\hline Germany & - & - & 0.16 & 0.17 & - \\
Austria & 0.42 & 0.95 & 0.69 & 0.51 & 1.22 \\
Netherlands & 0.06 & 0.05 & 0.12 & 0.15 & 0.34 \\
France & 0.94 & 0.51 & 0.53 & 0.38 & 0.62 \\
Spain & 0.64 & 0.44 & 0.52 & 0.48 & 1.02 \\
Italy & 0.24 & 0.33 & 0.33 & 0.42 & 0.99 \\
Denmark & 0.12 & 0.41 & 0.36 & 0.27 & 0.56 \\
Sweden & 0.27 & - & 0.14 & 0.13 & 0.20 \\
Norway & 0.31 & - & 0.06 & 0.05 & 0.13 \\
UK & 0.35 & 1.33 & 1.52 & 1.06 & 1.39 \\
\hline
\end{tabular}

Source: Institute of International Education and the Unesco Institute for Statistics Note: The percentages have been calculated by dividing the number of US students that study in a particular country (Open Doors, see Figure 7) by the number of enrolled degree students in that country (Unesco). The percentages in the 1992 column refer to 1990 for France and the UK. The percentages in the 1996 column refer to 1995 for France and Denmark. 
Table 2

Characteristics of education and research in economics at Dutch universities in 1980 and 2008

1980

Drs-diploma, 5-8 years of study $\quad$ BA and MA, 3+1 years of study

A drs could become member of the Then "aio" = employee who writes a

faculty

thesis

Some wrote a thesis

Gradual shift:

Often as a magnus opus

From employee to student

Introduction of course work

Use of term $\mathrm{PhD}$ rather than aio

Aim: Participation in national

Aim: Publish in international

discussion

(American) journals

Some researchers have an

Most researchers have an international

international focus

focus 
Figure 1

Quality and relevance of research per unit costs as a function of transferability (a) and costs of international research (b).
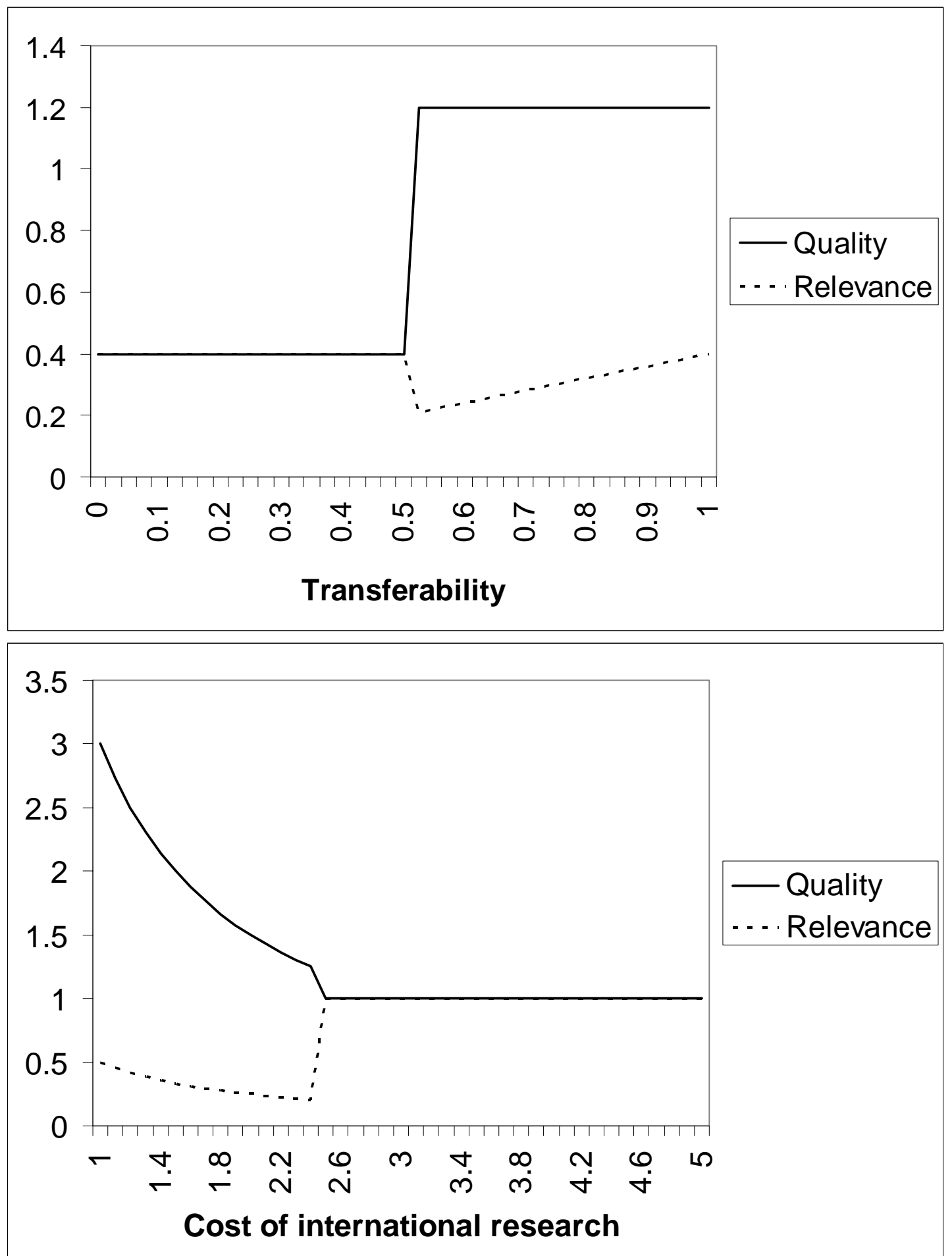

Note: The figure is based on the following parameters: $v_{q}=v_{r}=1, Q(n)=1$, $Q(N)=3, k=1$, and $K=3$ in panel a and $\tau=0.5$ in panel b. 
Figure 2

Gross enrollment ratios in Western European countries and the US, 1970-2006

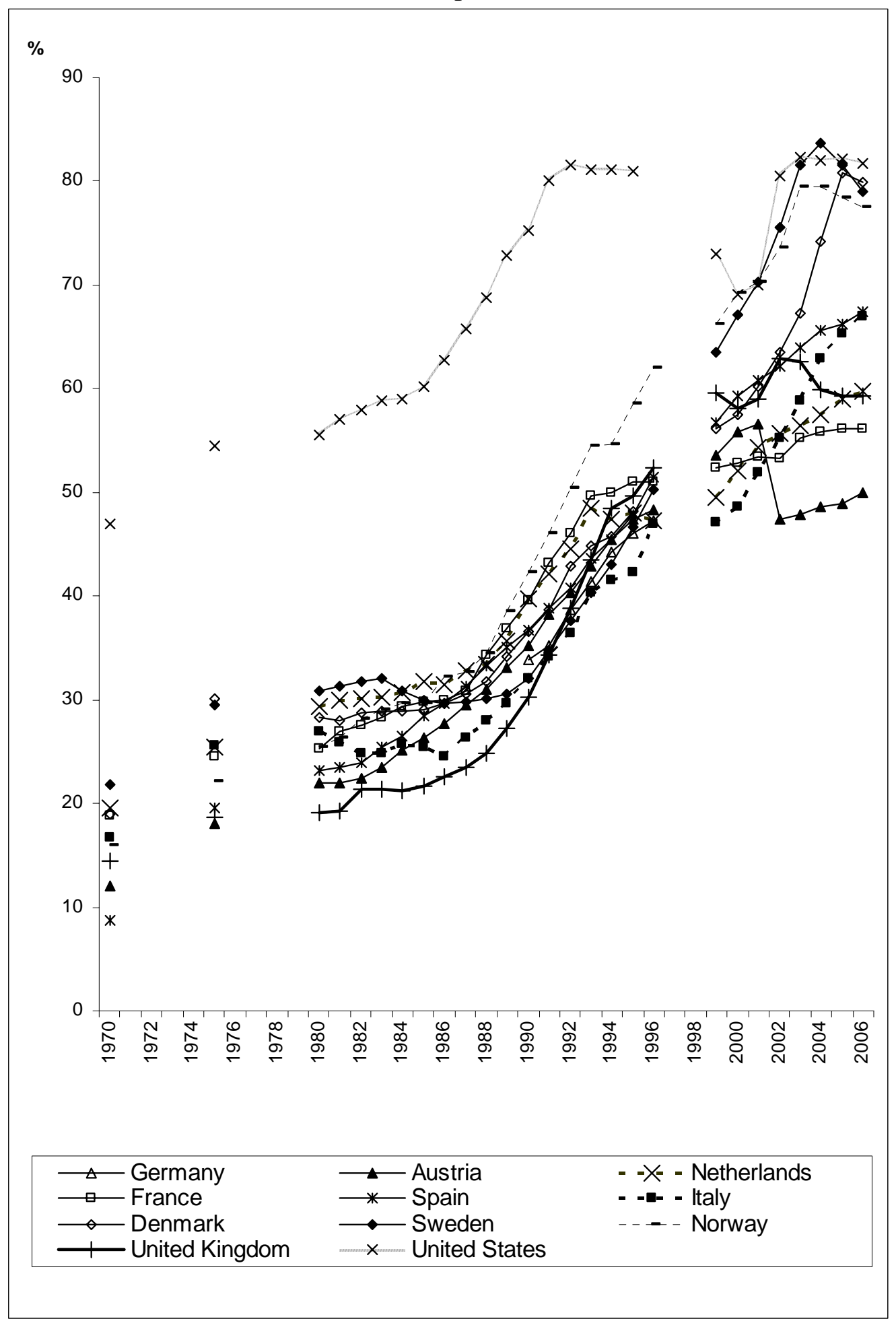

Source: Unesco Institute for Statistics

Notes: The gross enrollment ratio is defined as the number of students enrolled in tertiary education expressed as a percentage of the population in the theoretical age group for tertiary education. There may be changes in the measurement of the gross enrollment ratio between 1996 and 1999 for some countries, like the US. There also seems to be a break in the series for the US and Austria between 2001 and 2002. For Germany data is only available from 1990 to 1996. 
Figure 3

Total number of European and foreign (non-US) students in the US, 1949-2004

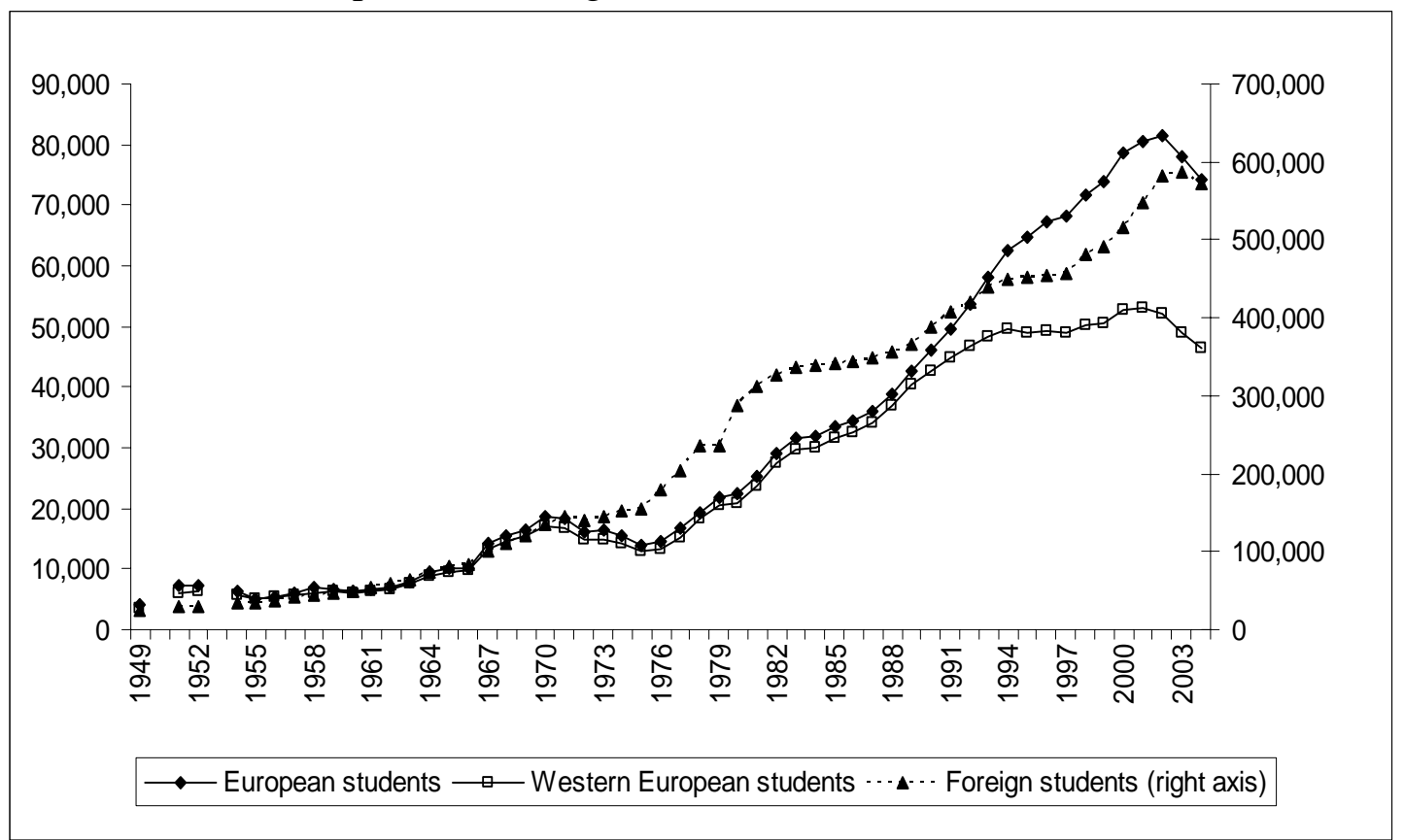

Source: Institute of International Education

Notes: The data has been drawn from the Open Doors database of the Institute of International Education. For international students in the US, Open Doors counts both enrolled degree students as well as students who are taking shorter non-degree courses. 
Figure 4

Students of Western European countries in the US as percentage of enrollment in home country, 1970-2006

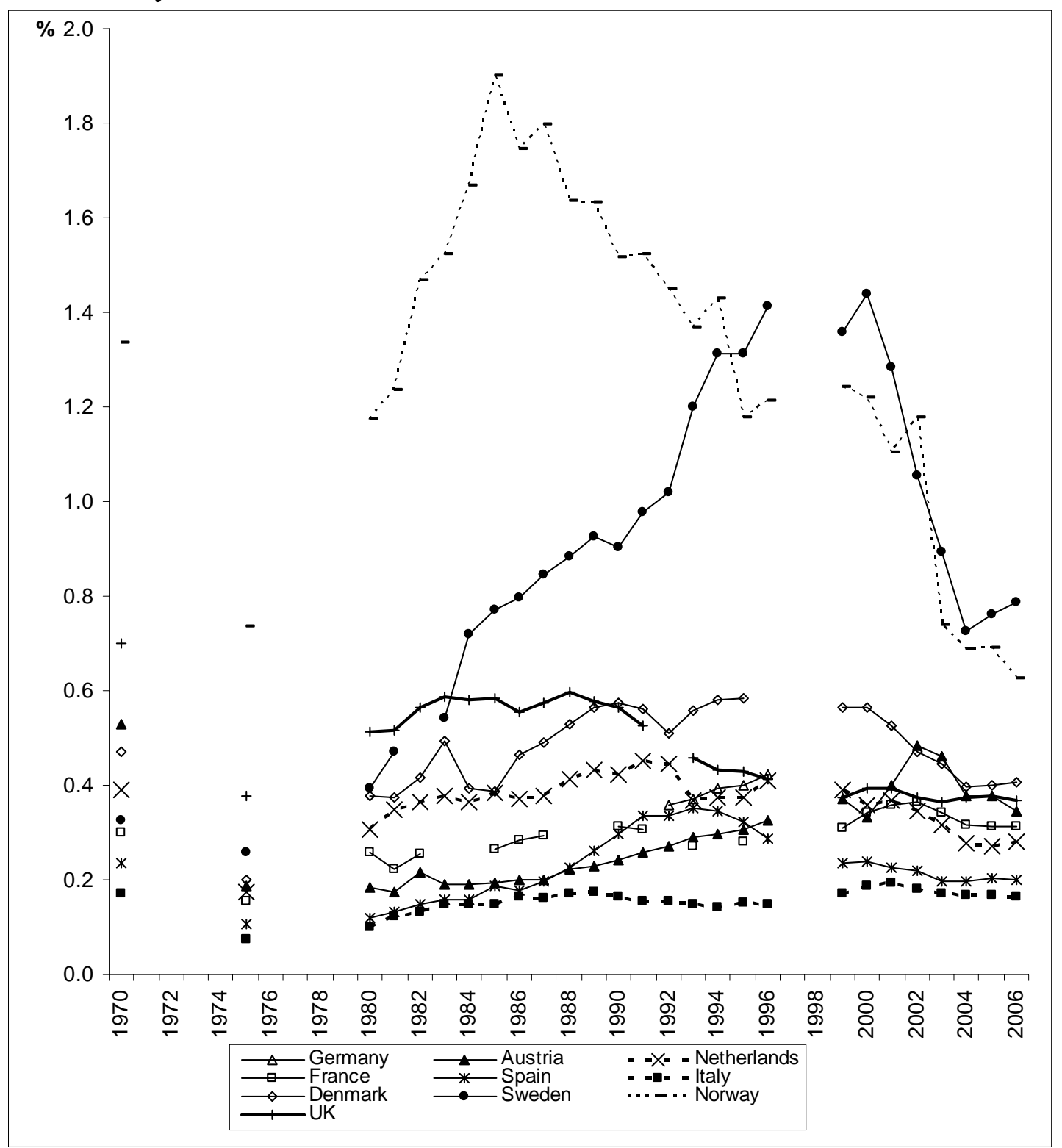

Source: Institute of International Education and the Unesco Institute for Statistics Note: The percentages have been calculated by dividing the number of students of a particular country in the US (Open Doors, see Figure 2) by the number of enrolled degree students in the respective home country (Unesco). 
Figure 5

Outbound mobile Western European students as percentage of enrollment in home country, 1999-2006

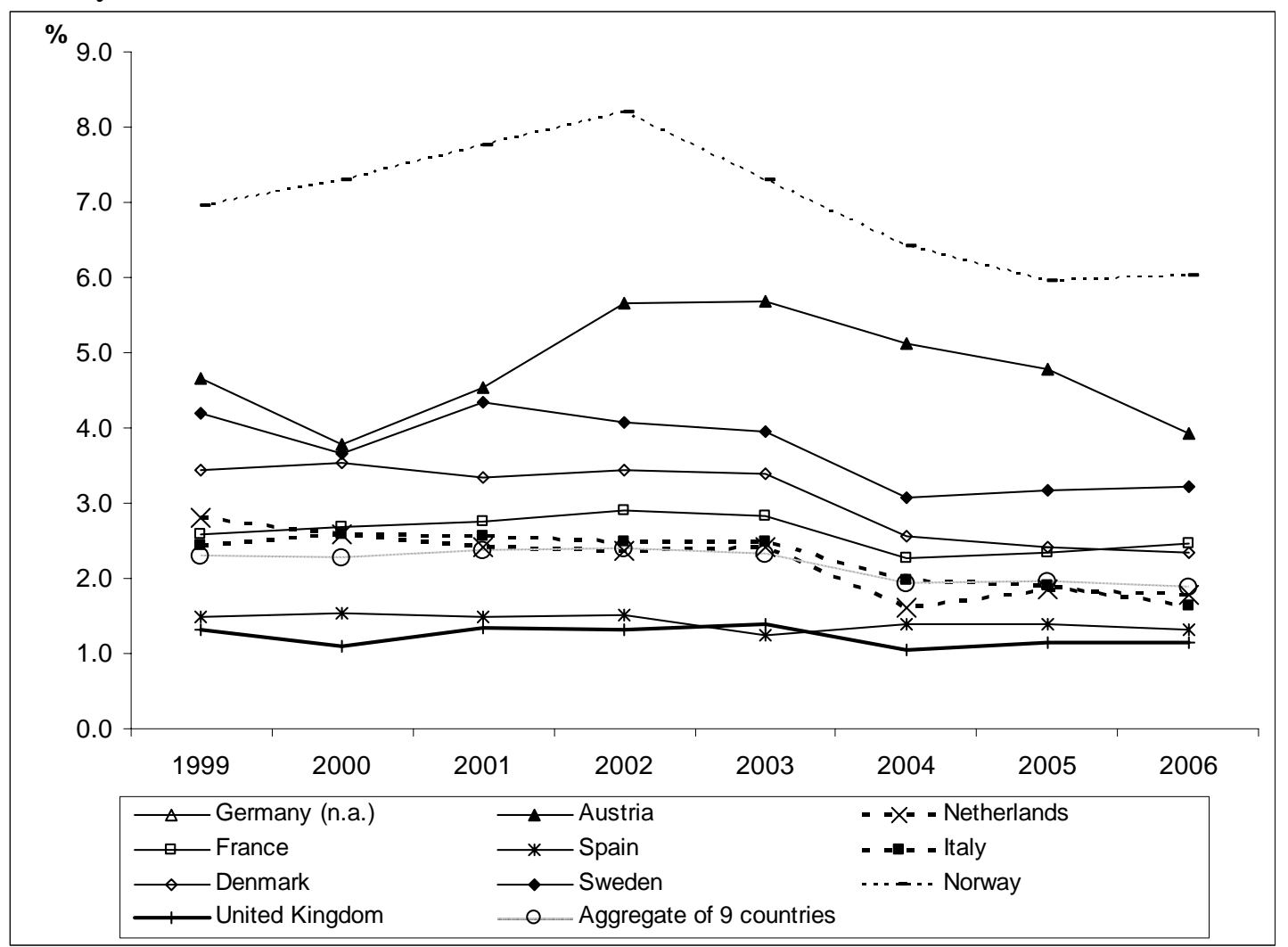

Source: Unesco Institute for Statistics

Notes: Unesco counts the number of degree students enrolled in the home country and in foreign countries. Home enrollment data is not available for Germany. 
Figure 6

Outbound mobile students that study in the US as percentage of total outbound mobility per country, 1999-2006

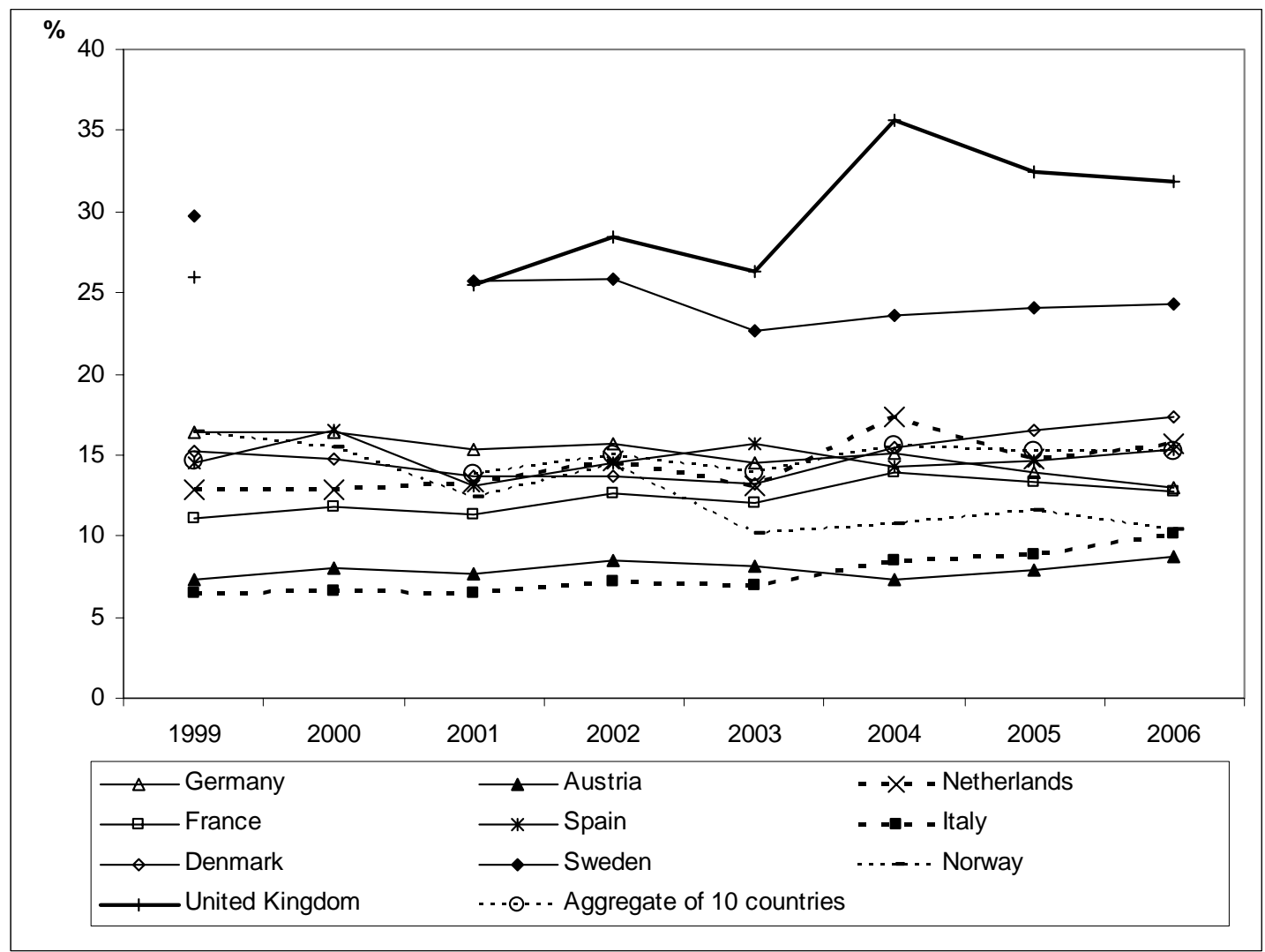

Source: Unesco Institute for Statistics

Note: Unesco counts the number of degree students enrolled in the home country and in foreign countries. 
Figure 7

Total number of US students abroad, 1955-2003

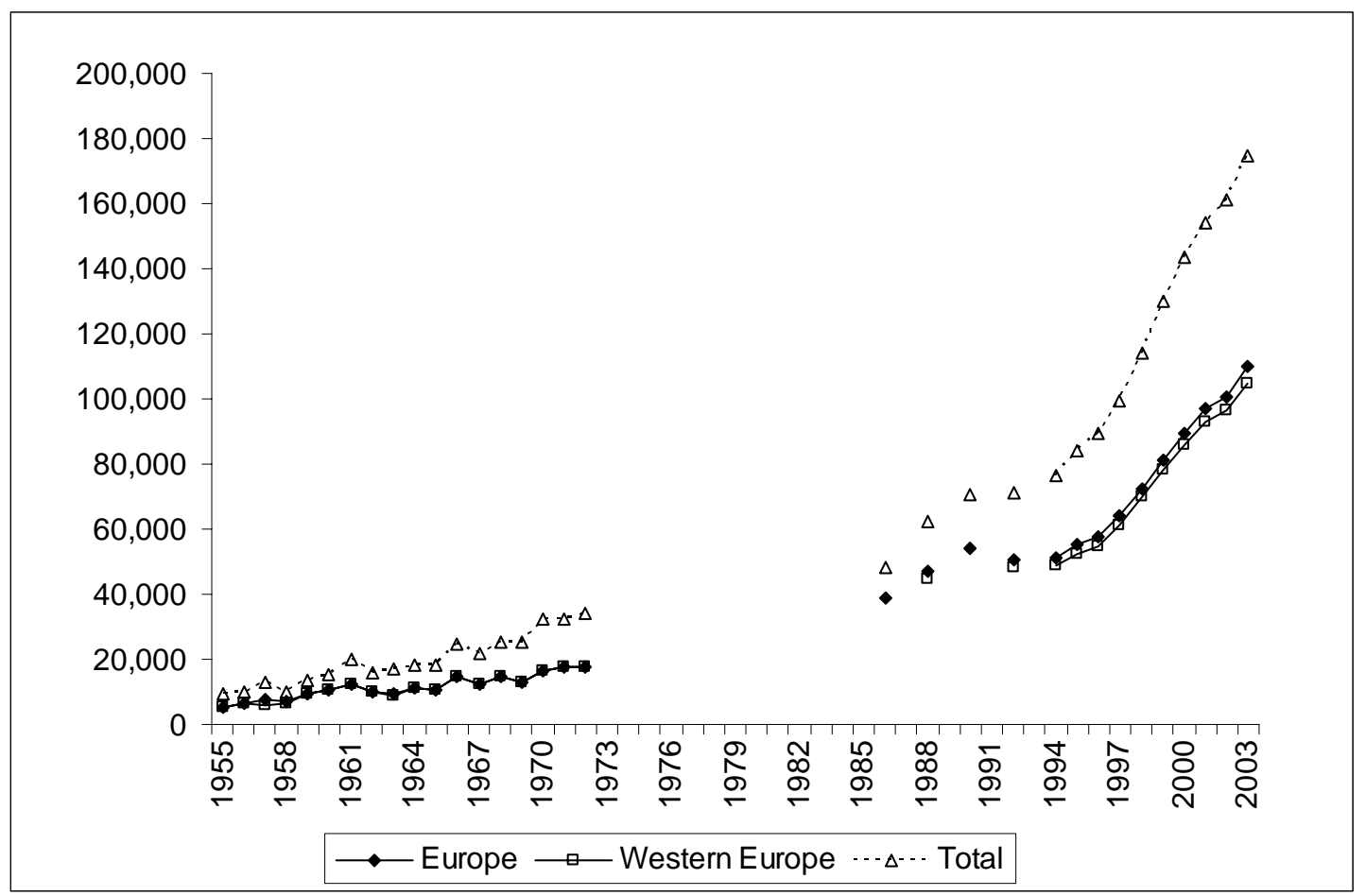

Source: Institute of International Education

Notes: The data has been drawn from the Open Doors database of the Institute of International Education. For Americans overseas, Open Doors counts the number of students that study abroad. This consists of short-term programs of one year or less which are held in another country, but which the American student receives credit for towards their US degree. There are far more Americans participating in these types of study abroad programs than are enrolled in degree courses overseas. The Unesco measures this enrollment, which equals about 48,000 students in 2006. 
Figure 8

Growth of higher education in the Netherlands, 1950-2006

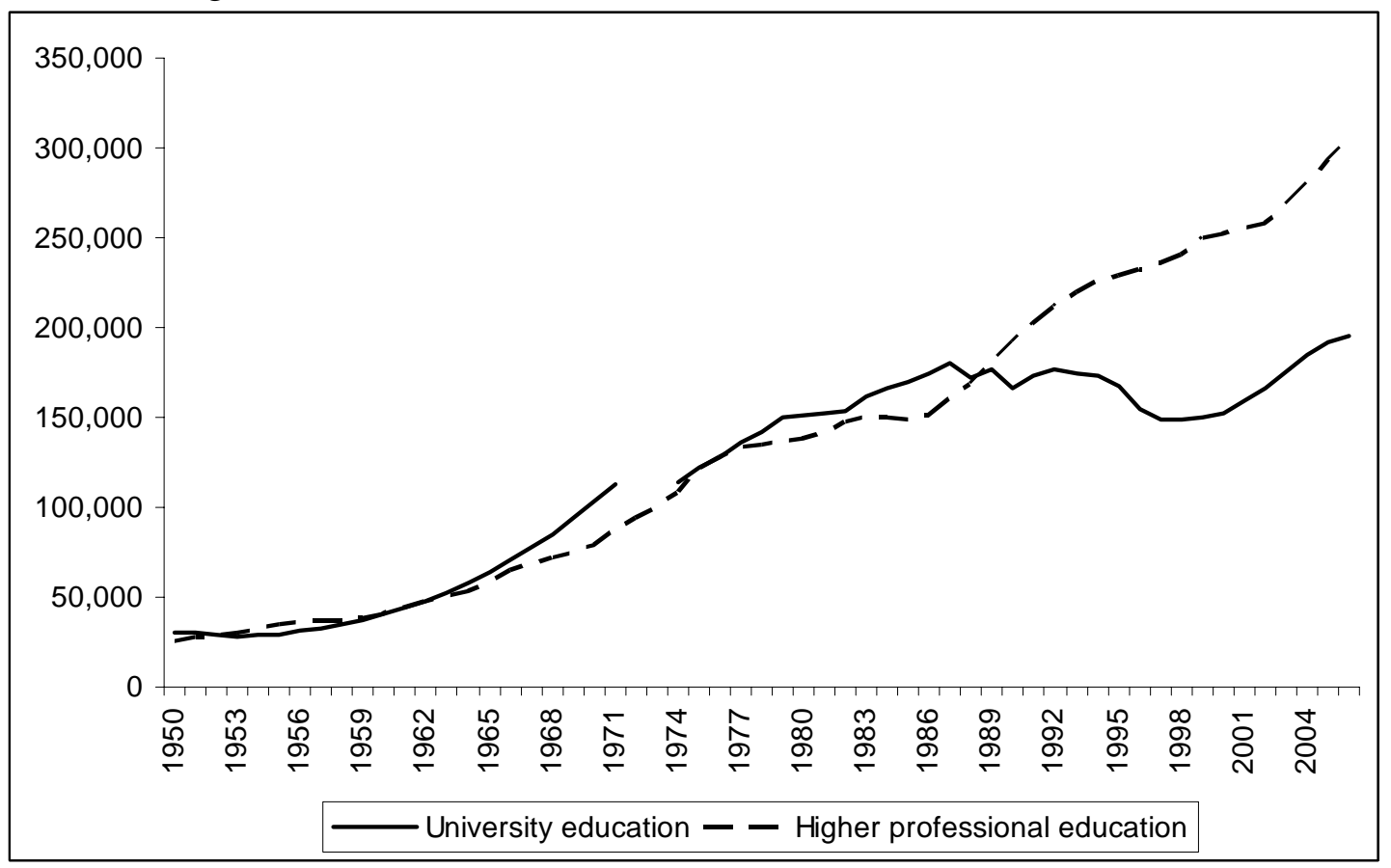

Source: Statistics Netherlands

Note: The data concerns students in full-time education. 
Figure 9

Students versus faculty at universities in the Netherlands, 1959-1994

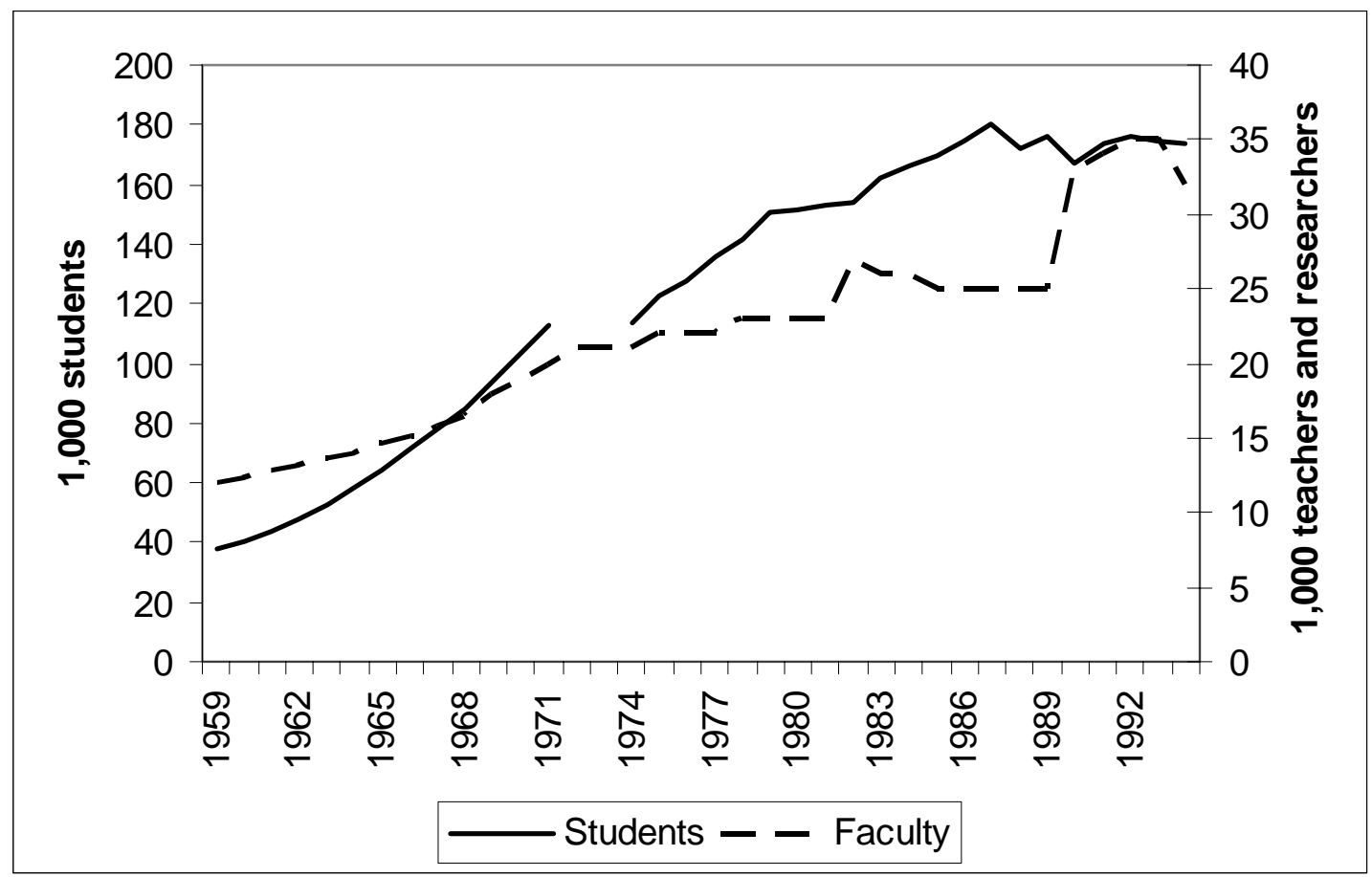

Source: Statistics Netherlands

Note: See Figure 8. 
Figure 10

Dutch and German students in the USA, 1949-2004

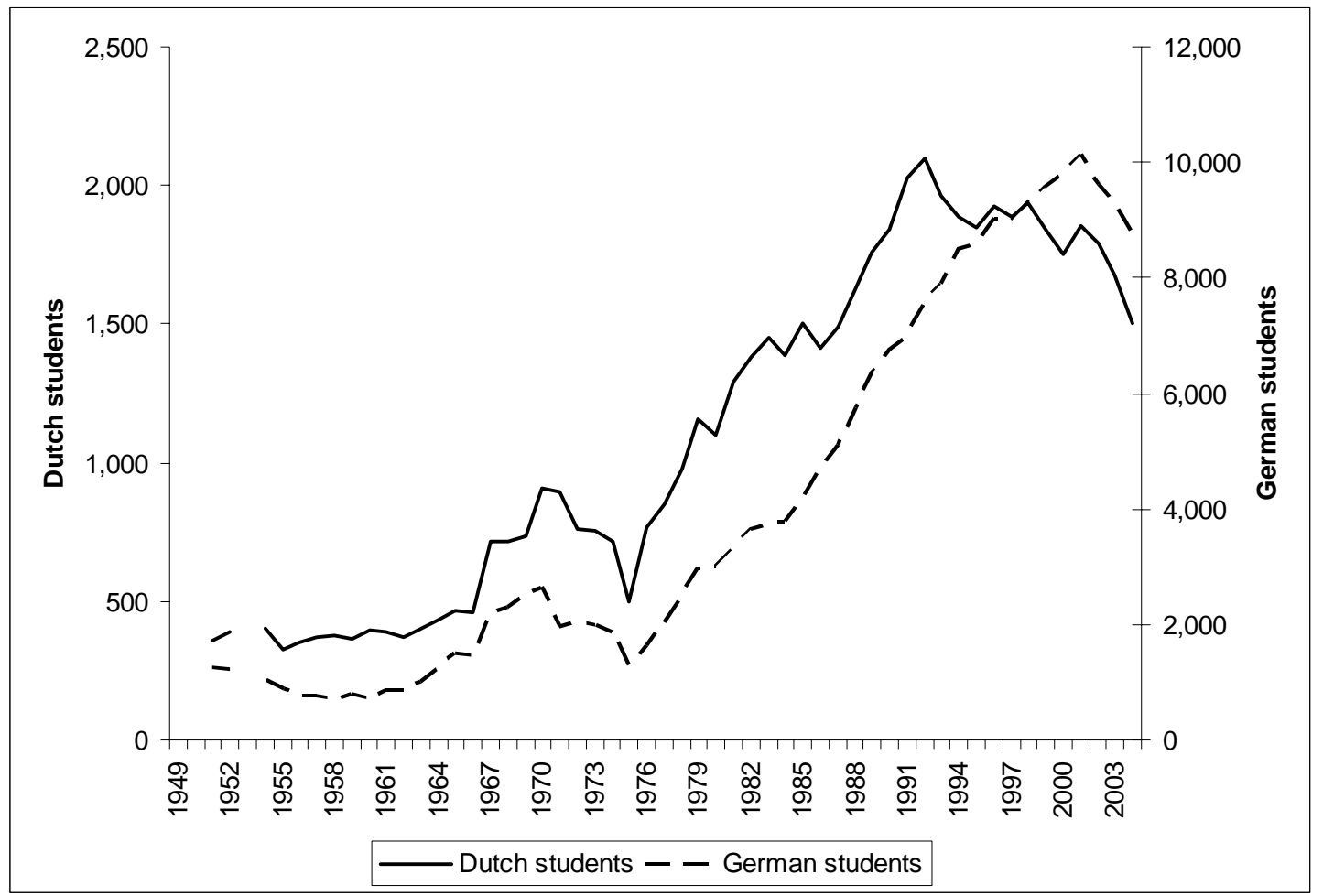

Source: Institute of International Education

Notes: See Figure 3 
Figure 11

Dutch university students and mobility flows between the Netherlands and the USA, 1949-2006

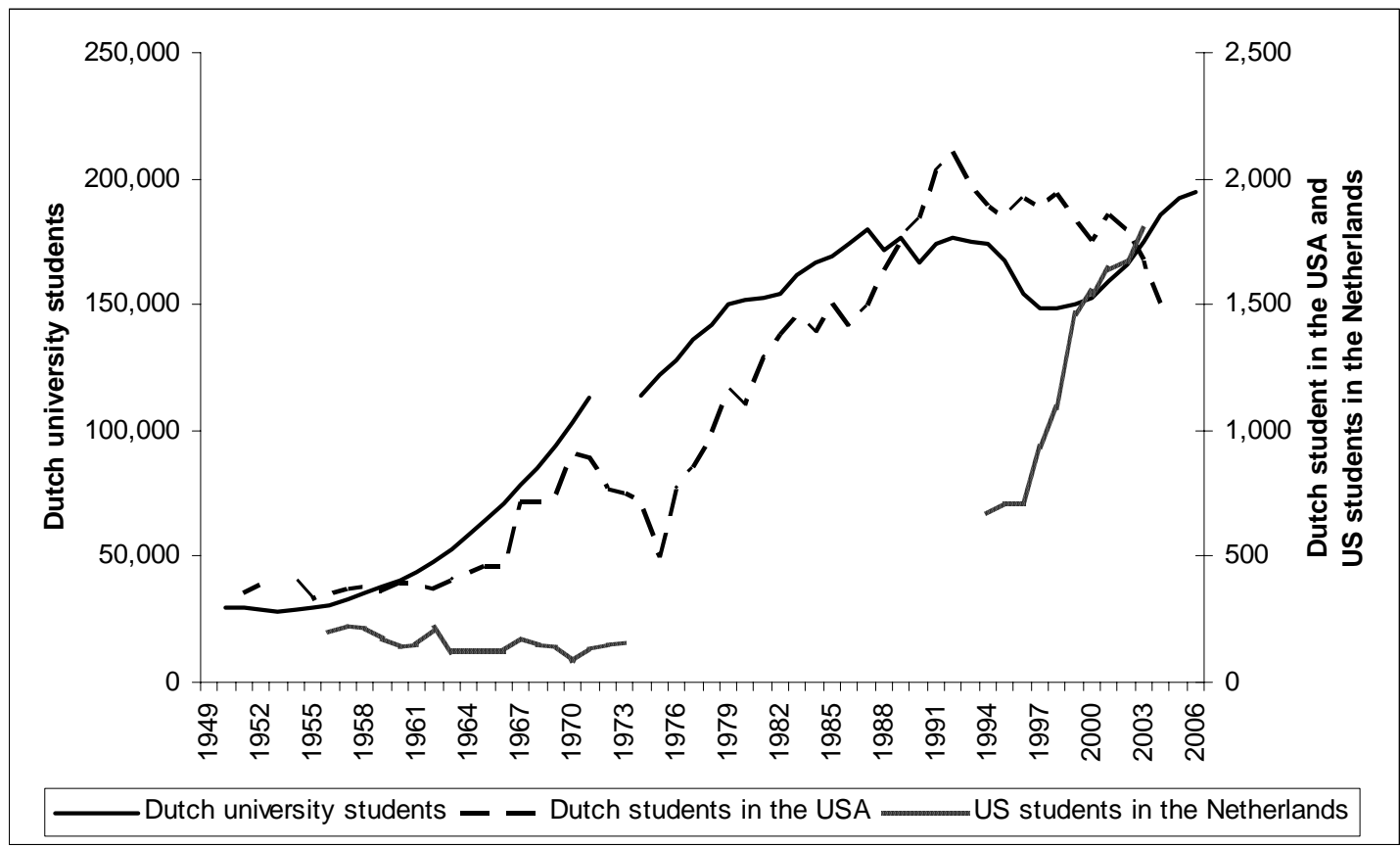

Sources: Statistics Netherlands and Institute of International Education Notes: See Figures 3, 7 and 8 
Figure 12

Foreign students as percentage of Dutch enrollment per discipline, 2004-2008

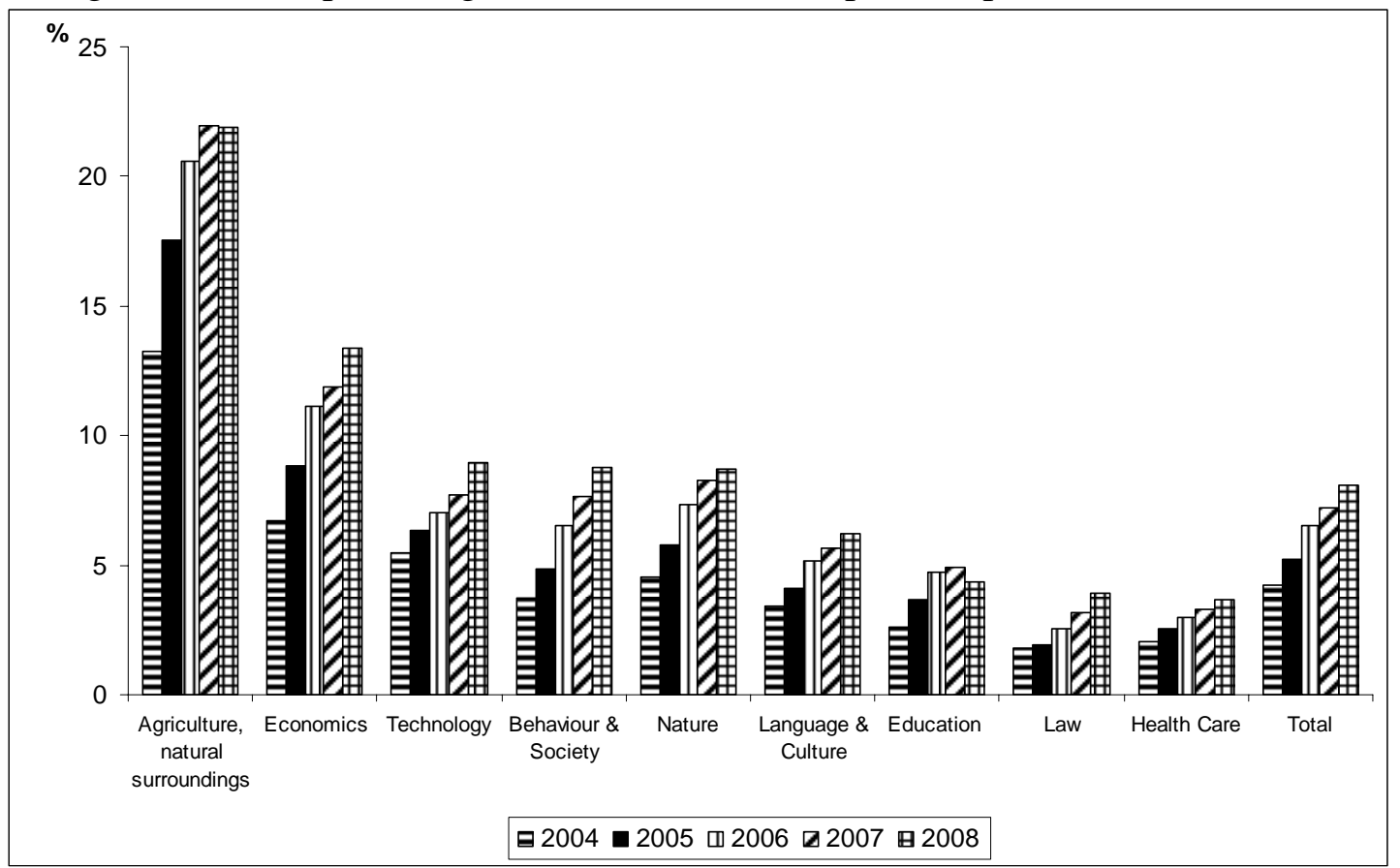

Source: Nuffic (2008)

Note: Data concerns foreign students enrolled at publicly funded Dutch universities. 
Figure 13

Number of PhDs and total enrollment at universities in the Netherlands, 1950-2005

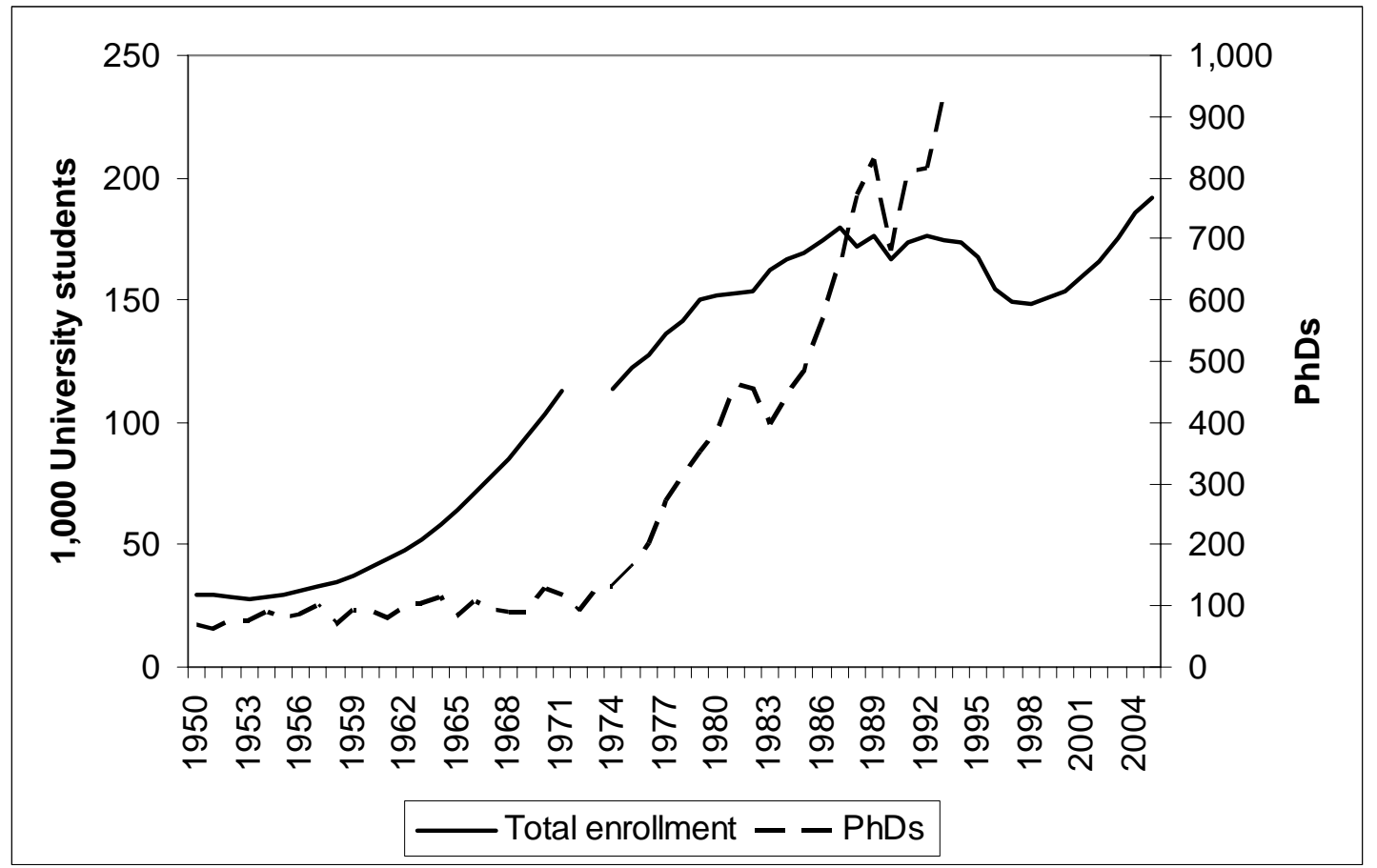

Sources: Statistics Netherlands and library of Maastricht University 
Figure 14

Average age of graduating PhDs by discipline in the Netherlands, 1970-1995

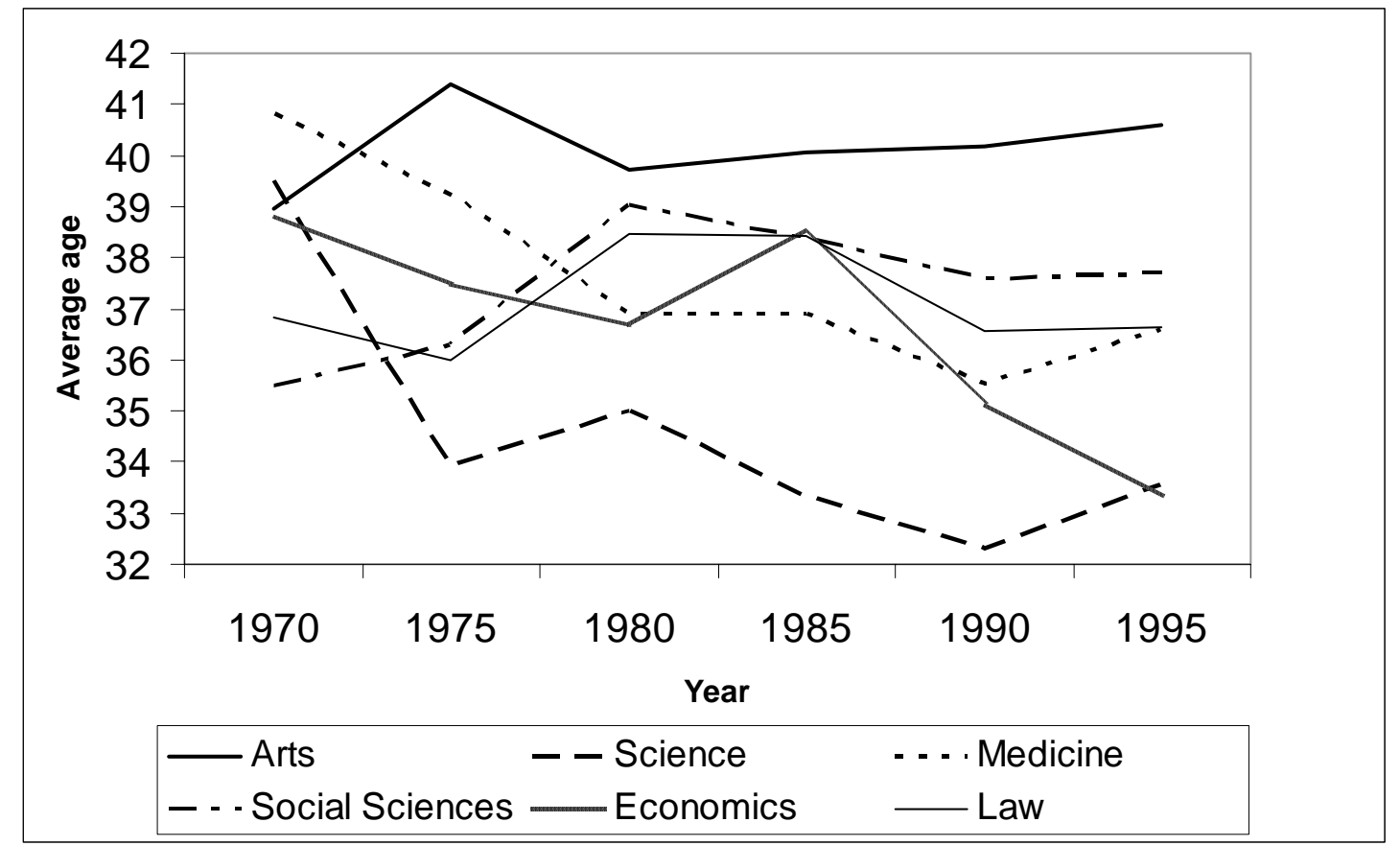

Source: Library of Maastricht University 
Figure 15

Percentage of doctoral dissertations in the home language, 1908-2007

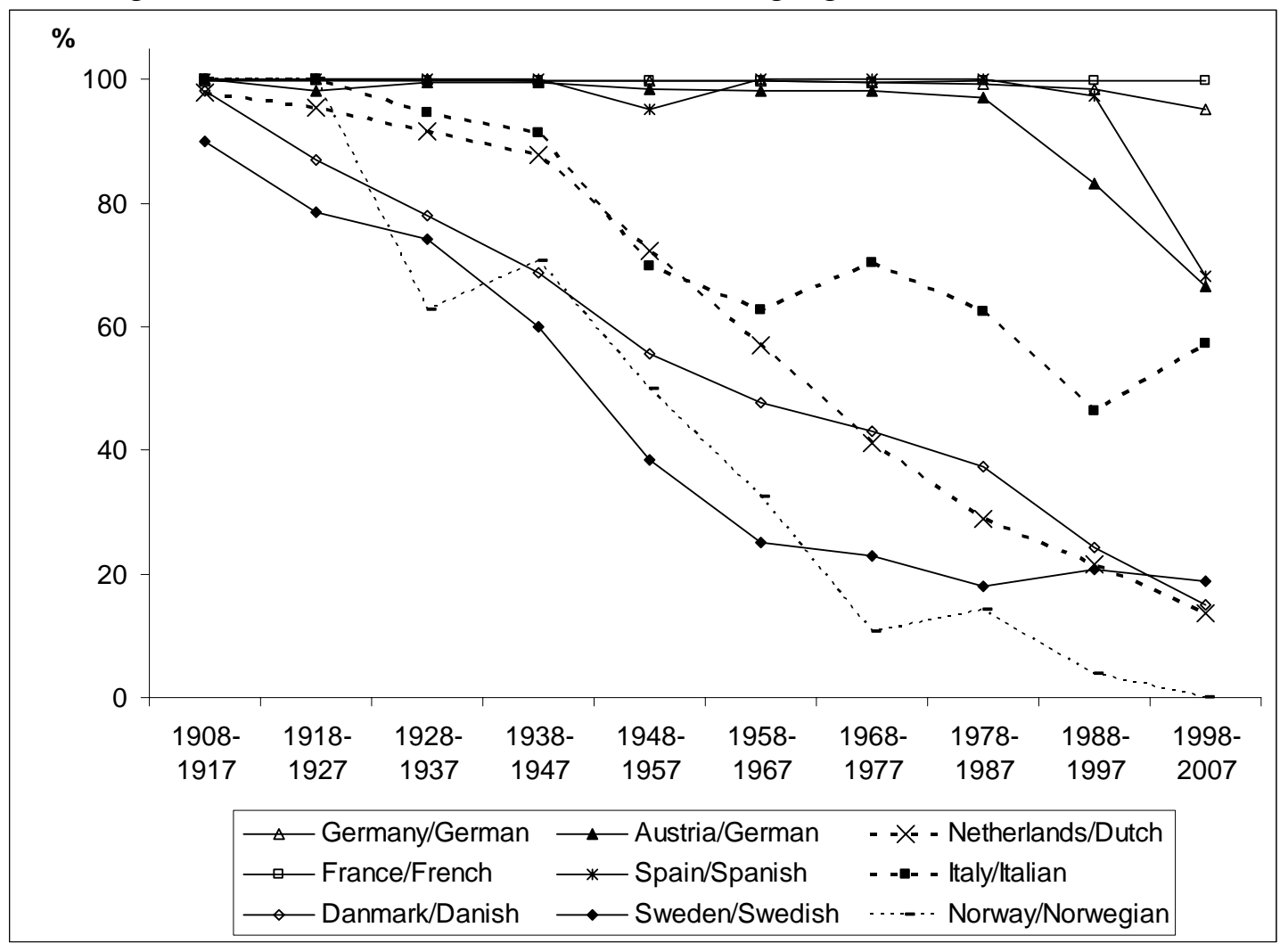

Source: Center for Research Libraries 
Figure 16

Shares of languages of doctoral dissertations in the Netherlands, 1674-1995

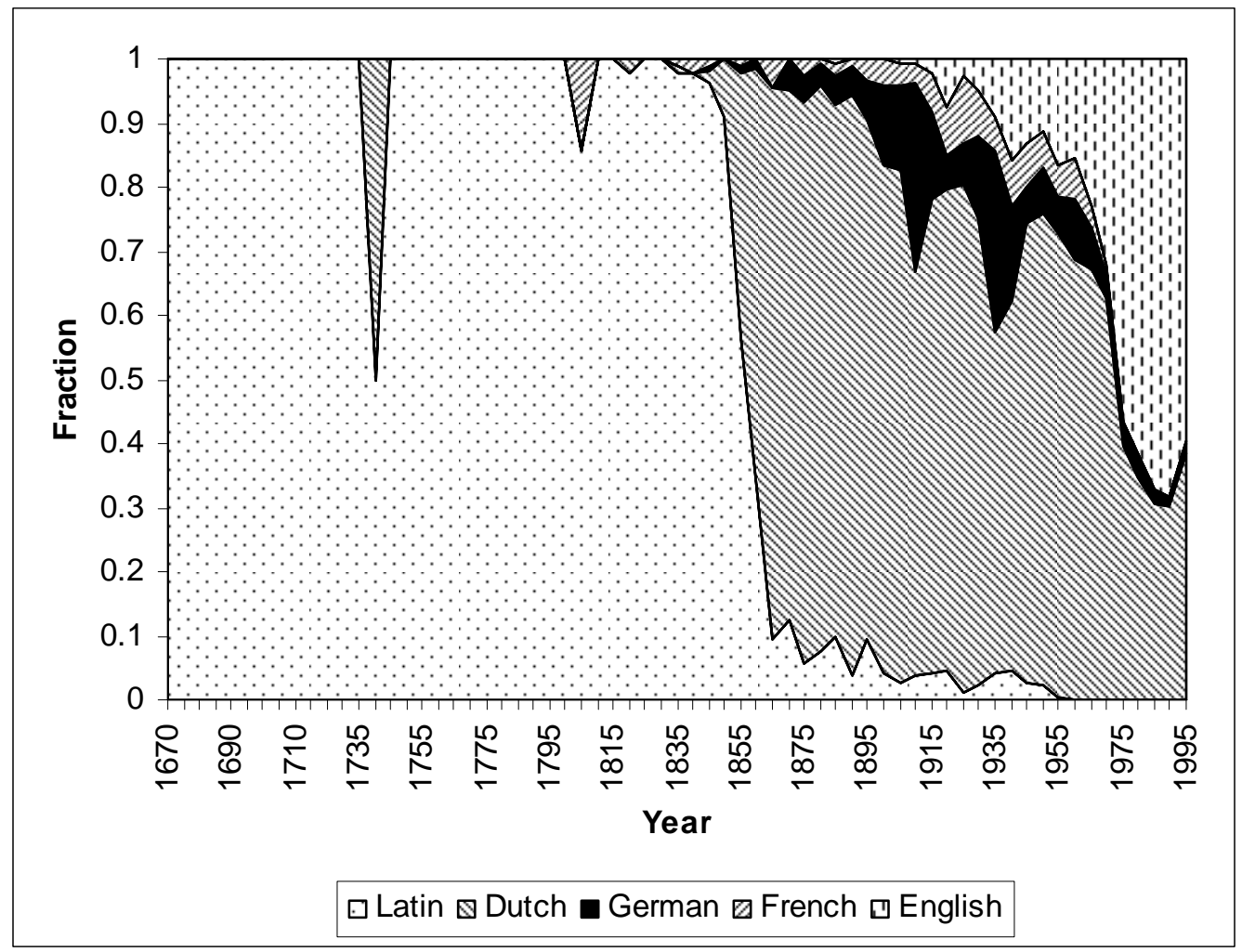

Source: Library of Maastricht University 
Figure 17

The fraction of doctoral dissertations published in English by discipline, the Netherlands 1945-1995

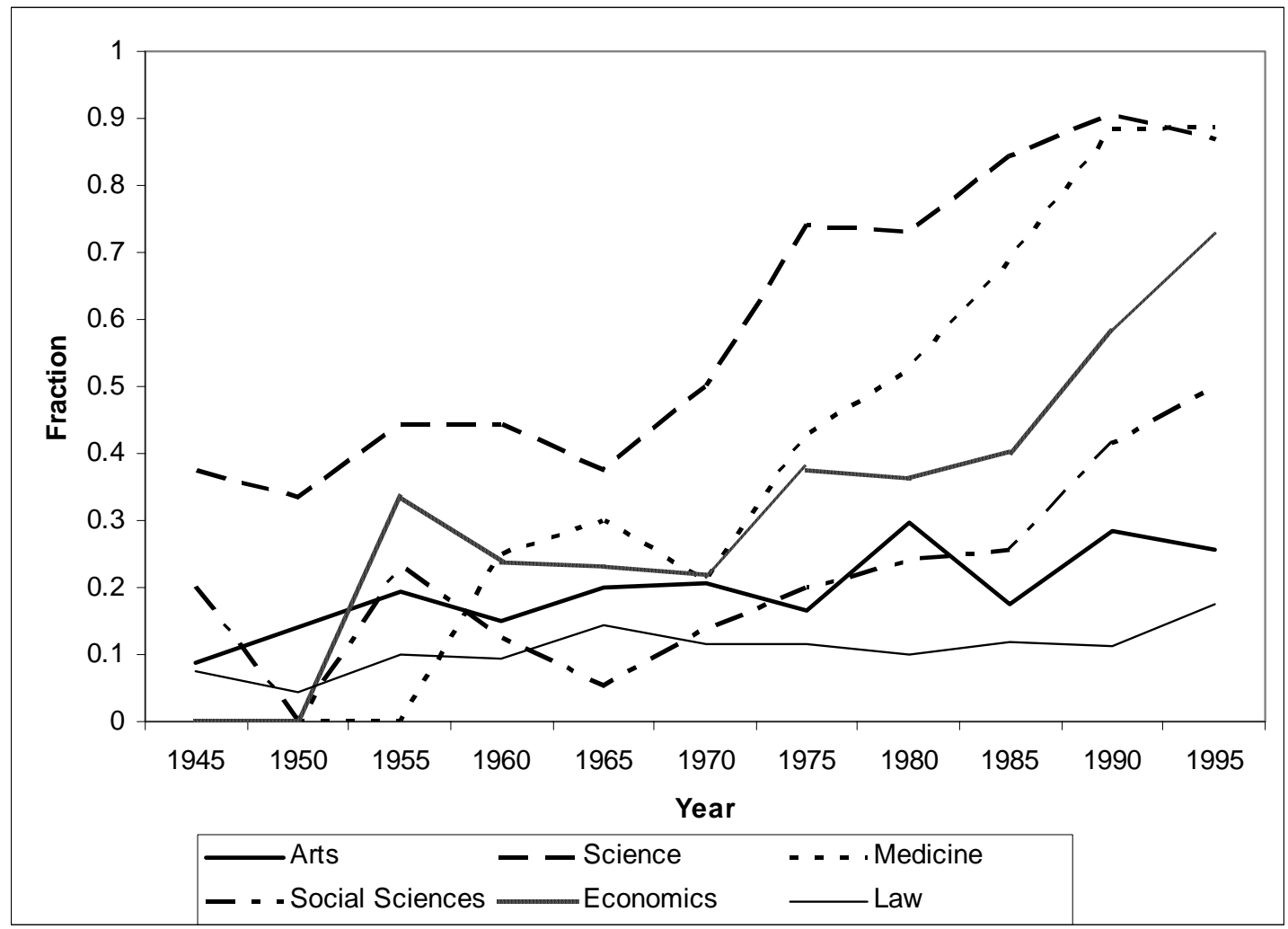

Source: Library of Maastricht University 
Figure 18

Language of Continental European Journals in Economics, 1844-2001

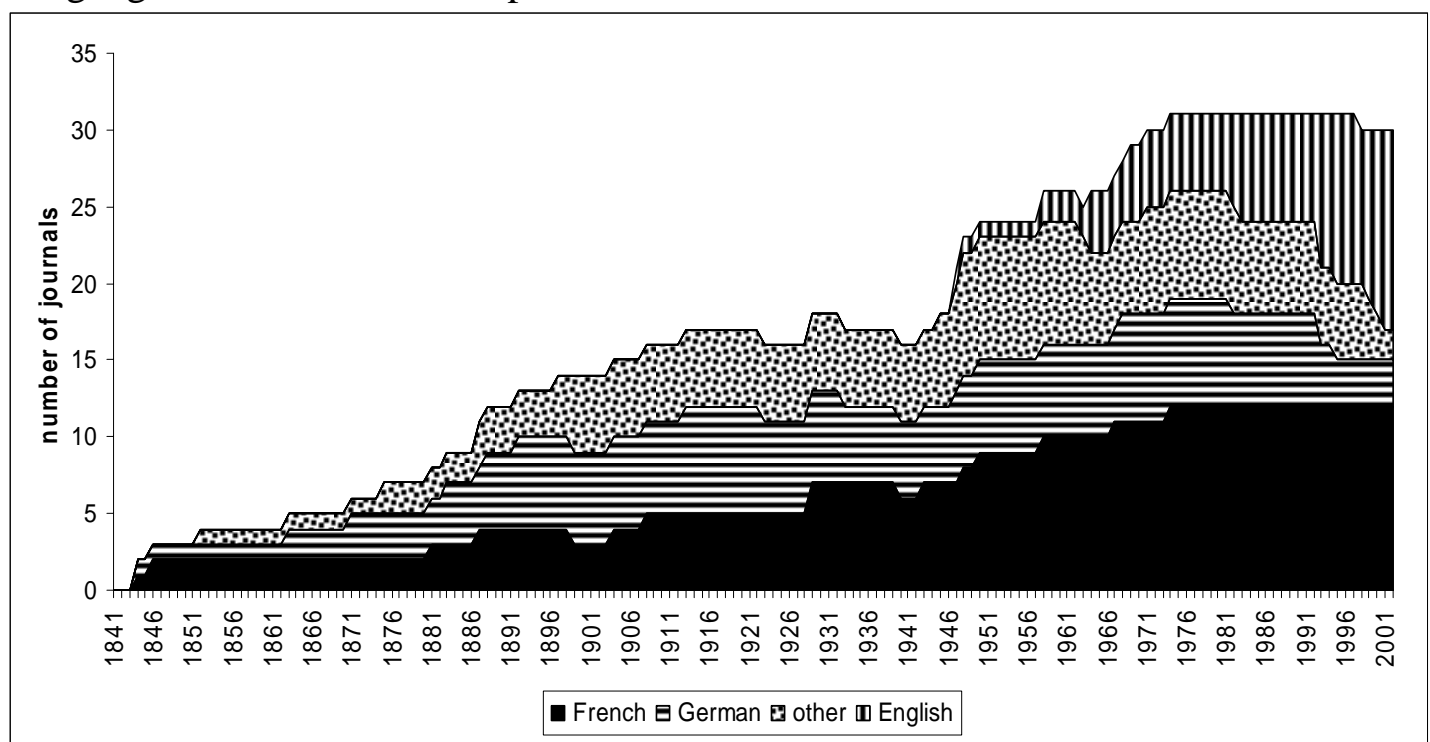

Sources: Fonseca, Periodicals Service Company \& Schmidt Periodicals GmbH and some additional sources 
Figure 19

Country of origin of English language economics journals in Anglo-American countries, 1859-1990

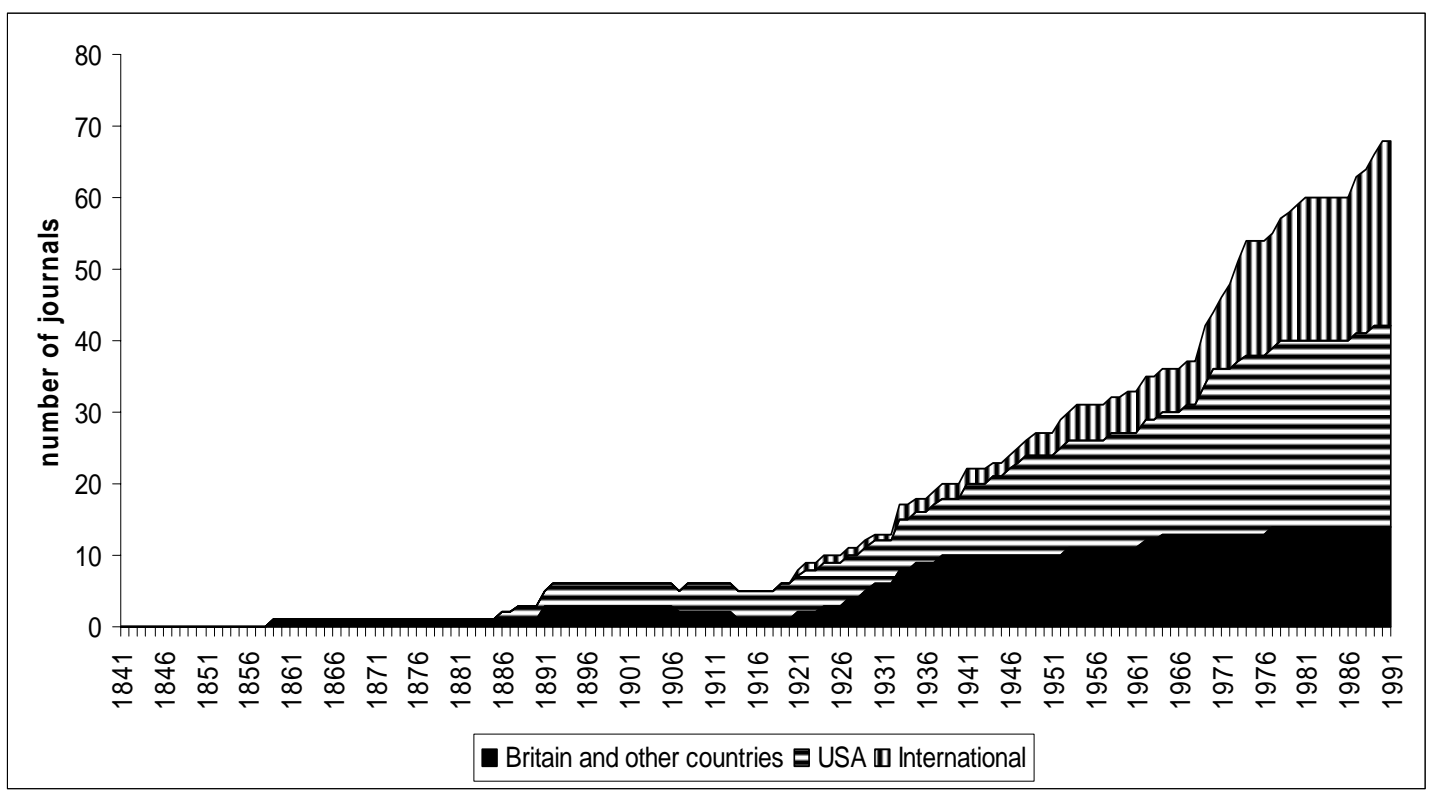

Sources: Fonseca, Periodicals Service Company \& Schmidt Periodicals GmbH and some additional sources 
Figure 20

The fraction of articles written in home language in De Economist (Dutch), Journal of Economics (German) and Research in Economics (Italian), 1930-2007

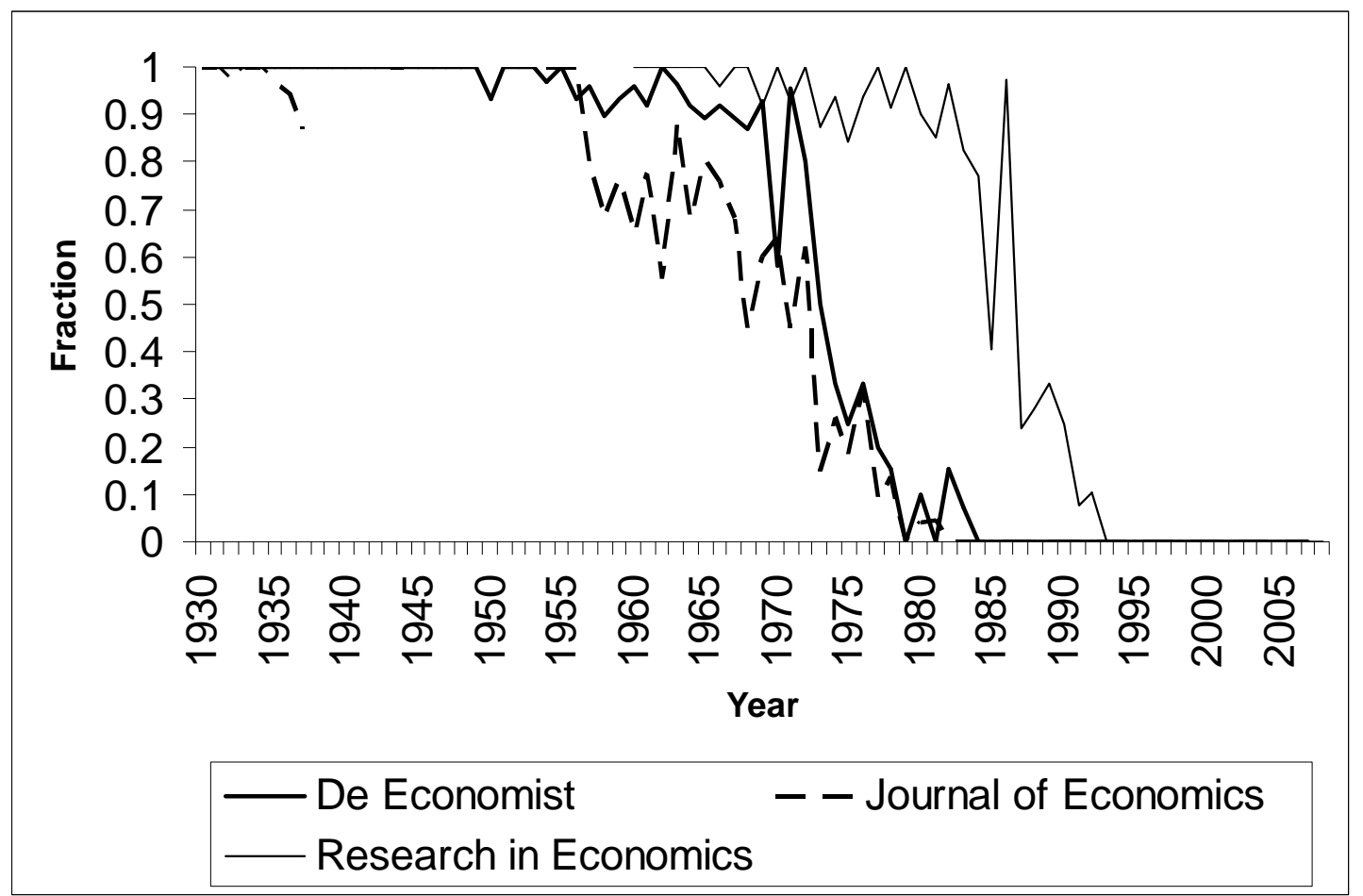

Sources: Springer, Elsevier and website of Research in Economics for 1960-1996 http://www.biblio.liuc.it/essper/schedper/p78.htm 
Figure 21

The fraction of articles written by native authors in De Economist (Netherlands), Journal of Economics (Austria/Germany) and Research in Economics (Italy), 19302007

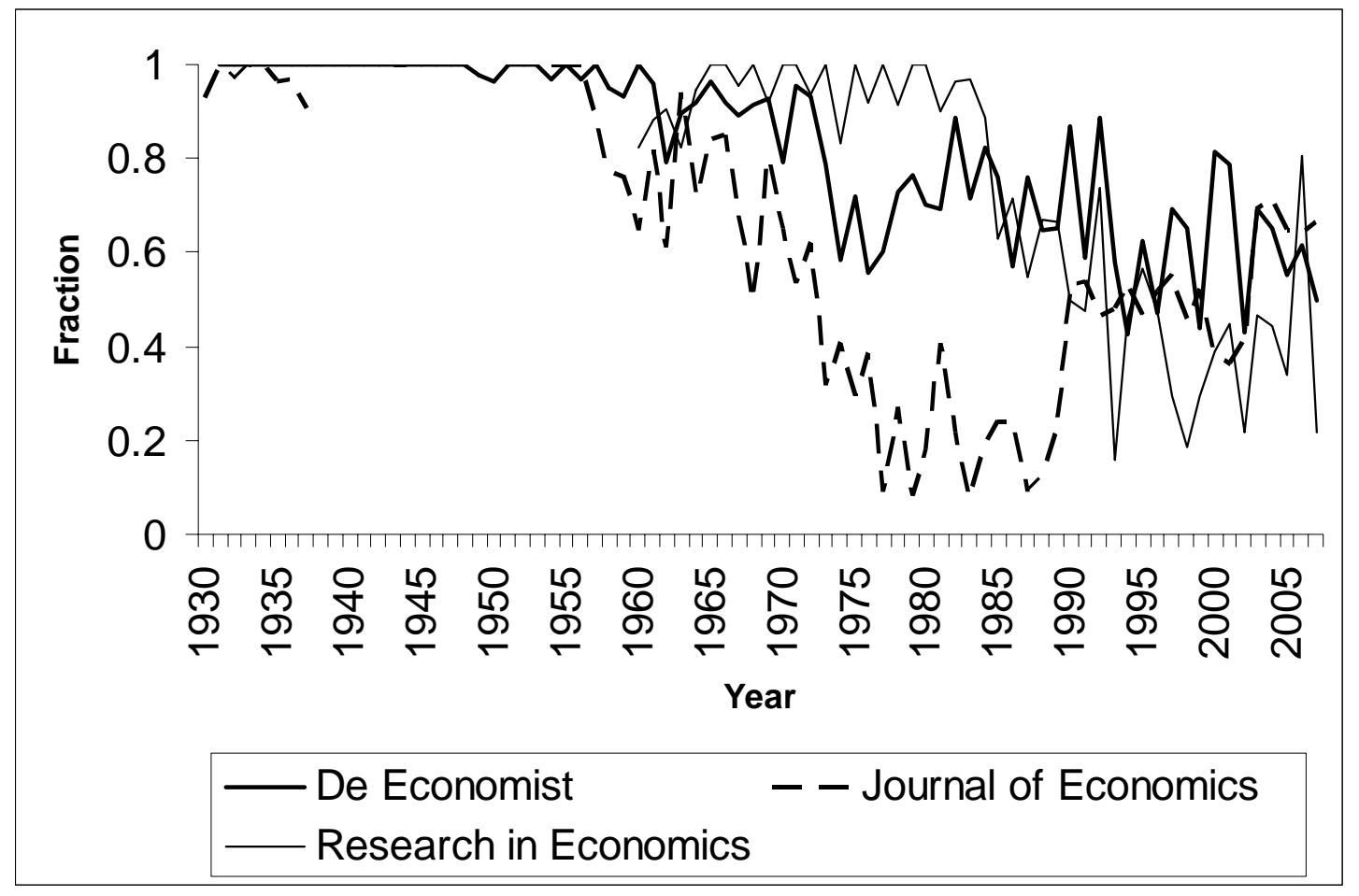

Sources: Springer, Elsevier and website of Research in Economics for 1960-1996 http://www.biblio.liuc.it/essper/schedper/p78.htm 
Figure 22

The fraction of references in English articles to publications in home language for De Economist (Dutch) and Journal of Economics (German), 1960-2007

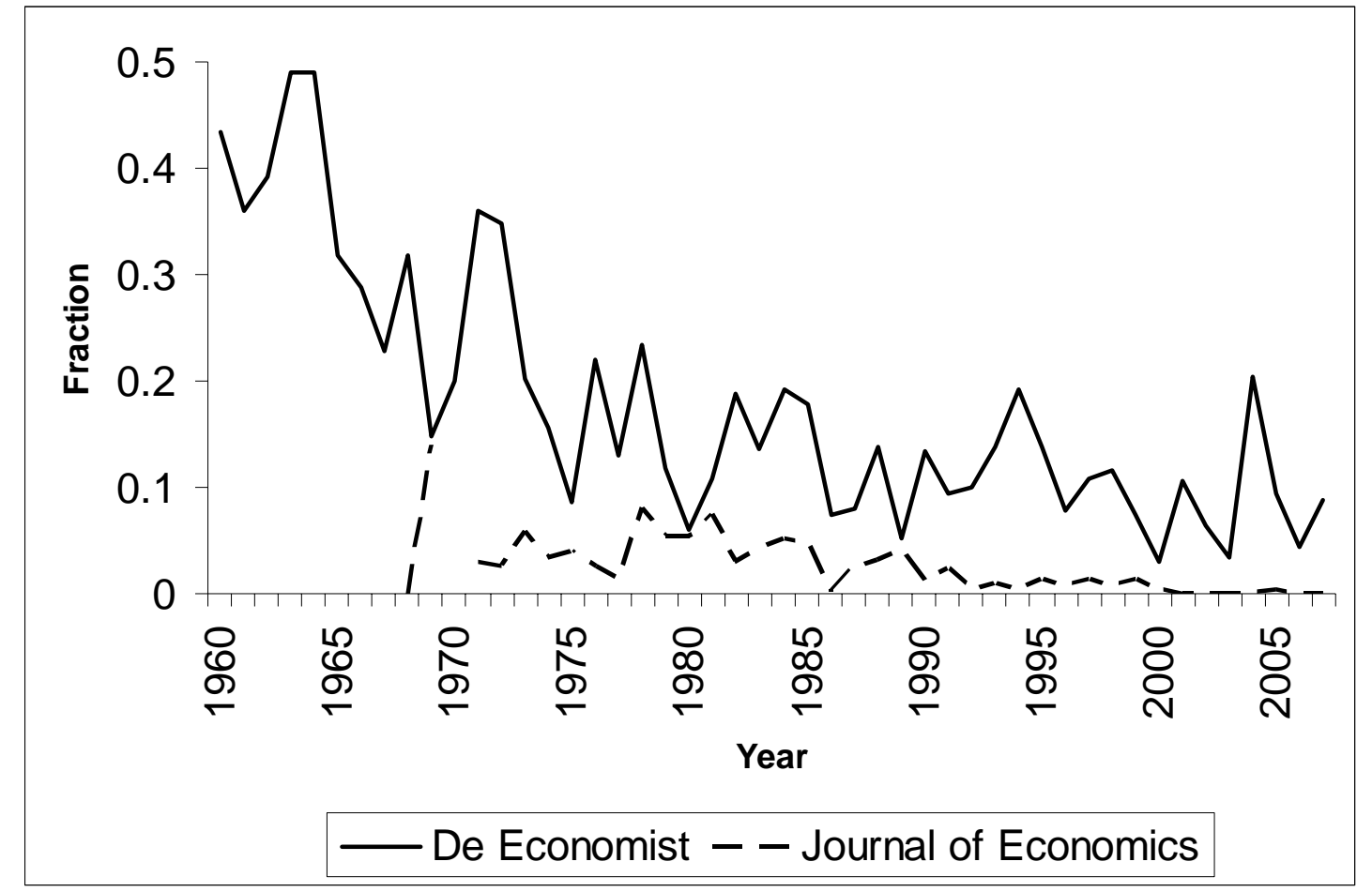

Source: Springer 
Annex to Figures 15, 18, 19 
Numbers of dissertations by country and language, 10-year periods 1908-2007

\begin{tabular}{|c|c|c|c|c|c|c|c|c|c|c|c|}
\hline \multirow[t]{4}{*}{ Austria } & year & $\begin{array}{r}\text { 1908- } \\
1917\end{array}$ & $\begin{array}{r}\text { 1918- } \\
1927\end{array}$ & $\begin{array}{r}\text { 1928- } \\
1937\end{array}$ & $\begin{array}{r}\text { 1938- } \\
1947\end{array}$ & $\begin{array}{r}\text { 1948- } \\
1957\end{array}$ & $\begin{array}{r}1958- \\
1967\end{array}$ & $\begin{array}{r}\text { 1968- } \\
1977\end{array}$ & $\begin{array}{r}\text { 1978- } \\
1987\end{array}$ & $\begin{array}{r}\text { 1988- } \\
1997\end{array}$ & $\begin{array}{r}1998- \\
2007\end{array}$ \\
\hline & & & 112 & 245 & 191 & 375 & 302 & 336 & 205 & 79 & 22 \\
\hline & English & 0 & 2 & 1 & 1 & 6 & 6 & 6 & 6 & 16 & 11 \\
\hline & \% German & 100 & 98 & 100 & 99 & 98 & 98 & 98 & 97 & 83 & 67 \\
\hline \multirow[t]{4}{*}{$\begin{array}{l}\text { Germany, } \\
\text { West }\end{array}$} & year & $\begin{array}{c}1908- \\
1917\end{array}$ & $\begin{array}{c}1918- \\
1927\end{array}$ & $\begin{array}{c}1928- \\
1937\end{array}$ & $\begin{array}{c}1938- \\
1947\end{array}$ & $\begin{array}{c}1948- \\
1957\end{array}$ & $\begin{array}{r}1958- \\
1967\end{array}$ & $\begin{array}{c}\text { 1968- } \\
1977\end{array}$ & $\begin{array}{c}1978- \\
1987\end{array}$ & $\begin{array}{c}1988- \\
1997\end{array}$ & $\begin{array}{r}1998- \\
2007\end{array}$ \\
\hline & German & & 34764 & 60550 & 11833 & 11020 & 42177 & 63229 & 63253 & 70751 & 24594 \\
\hline & English & 56 & 10 & 23 & 13 & 21 & 80 & 269 & 514 & 1042 & 1222 \\
\hline & \%German & 100 & 100 & 100 & 100 & 100 & 100 & 100 & 99 & 99 & 95 \\
\hline \multirow[t]{5}{*}{ Netherlands } & year & $\begin{array}{c}1908- \\
1917\end{array}$ & $\begin{array}{c}1918- \\
1927\end{array}$ & $\begin{array}{c}1928- \\
1937\end{array}$ & $\begin{array}{c}1938- \\
1947\end{array}$ & $\begin{array}{c}1948- \\
1957\end{array}$ & $\begin{array}{r}1958- \\
1967\end{array}$ & $\begin{array}{c}1968- \\
1977\end{array}$ & $\begin{array}{c}1978- \\
1987\end{array}$ & $\begin{array}{c}1988- \\
1997\end{array}$ & $\begin{array}{r}1998- \\
2007\end{array}$ \\
\hline & Dutch & 622 & 1207 & 1978 & 1448 & 1643 & 1648 & 1796 & 1360 & 1169 & 435 \\
\hline & English & 13 & 57 & 183 & 201 & 630 & 1243 & 2551 & 3342 & 4287 & 2771 \\
\hline & \% Dutch & 98 & 95 & 92 & 88 & 72 & 57 & 41 & 29 & 21 & 14 \\
\hline & year & $\begin{array}{c}1908- \\
1917\end{array}$ & $\begin{array}{c}1918- \\
1927\end{array}$ & $\begin{array}{c}\text { 1928- } \\
1937\end{array}$ & $\begin{array}{c}1938- \\
1947\end{array}$ & $\begin{array}{c}1948- \\
1957\end{array}$ & $\begin{array}{c}1958- \\
1967\end{array}$ & $\begin{array}{c}\text { 1968- } \\
1977\end{array}$ & $\begin{array}{c}1978- \\
1987\end{array}$ & $\begin{array}{c}\text { 1988- } \\
1997\end{array}$ & $\begin{array}{r}1998- \\
2007\end{array}$ \\
\hline France & French & 7148 & 10187 & 8733 & 6808 & 4861 & 10331 & 18213 & 6993 & 18120 & 7591 \\
\hline
\end{tabular}




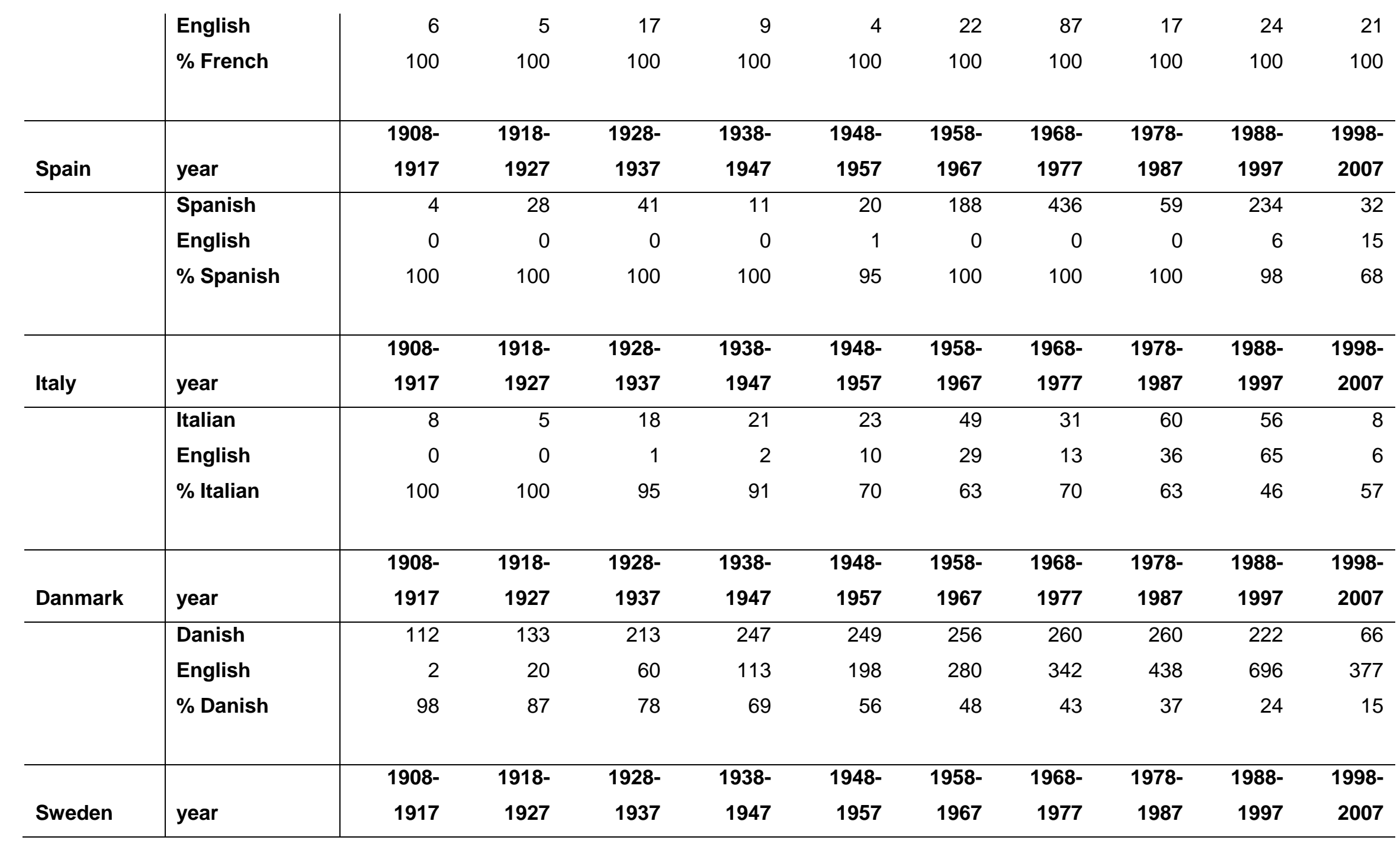




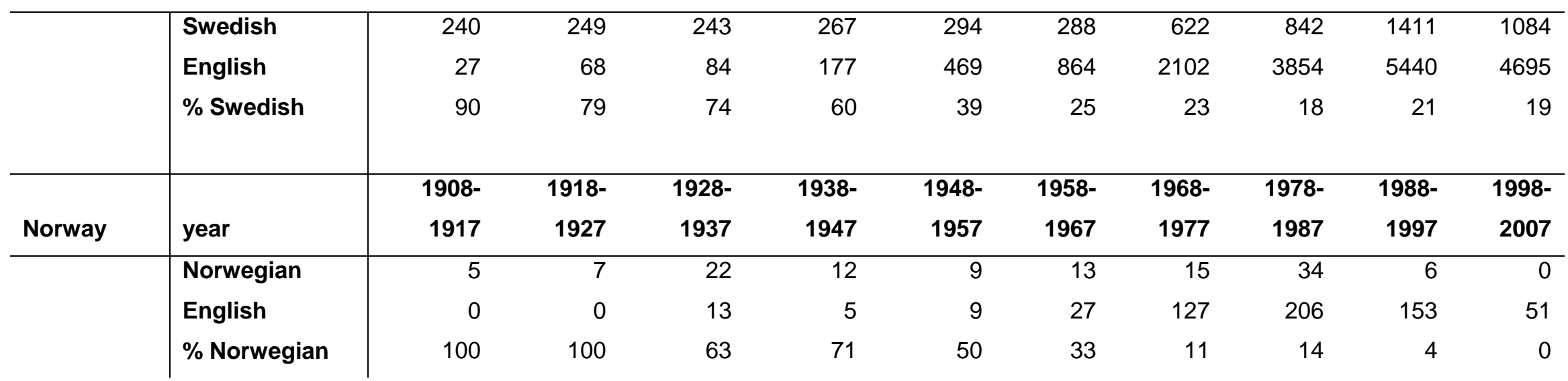

Source: Center for Research Libraries (CRL) 
Language of Continental European academic journals in economics

\begin{tabular}{|c|c|c|c|c|c|}
\hline Country & $\begin{array}{l}\text { Original } \\
\text { language }\end{array}$ & National journal name & $\begin{array}{l}\text { English journal } \\
\text { name }\end{array}$ & Publishing years & $\begin{array}{l}\text { Year of } \\
\text { publishing } \\
\text { solely English } \\
\text { articles }\end{array}$ \\
\hline Austria & German & Zeitschrift für Nationalökonomie & Journal of Economics & 1892- & 1982 \\
\hline Belgium & French & Revue économique internationale & - & $1904-1940$ & $\begin{array}{ll}----- \\
\end{array}$ \\
\hline Belgium & French & $\begin{array}{l}\text { Recherches Economiques de } \\
\text { Louvain }\end{array}$ & $\begin{array}{l}\text { Louvain Economic } \\
\text { Review }\end{array}$ & 1929- & $\begin{array}{l}\text {---- Still partly } \\
\text { in French }\end{array}$ \\
\hline Belgium & French & Cahiers économiques de Bruxelles & $\begin{array}{l}\text { Brussels Economic } \\
\text { Review }\end{array}$ & 1958- & $\begin{array}{l}\text {----- Still mix of } \\
\text { French and } \\
\text { English } \\
\text { language }\end{array}$ \\
\hline Europe & English & European Economic Review & - & 1969- & 1969 \\
\hline France & French & $\begin{array}{l}\text { Annuaire de l'économie politique et } \\
\text { de la statistique }\end{array}$ & - & 1844-1899 & ------ \\
\hline France & French & Annales d'Économie Politique & - & 1846- & $\begin{array}{l}\text {----- Still in } \\
\text { French }\end{array}$ \\
\hline France & French & Revue d'économie politique & - & 1887- & ------ Still \\
\hline
\end{tabular}




\begin{tabular}{|c|c|c|c|c|c|}
\hline & & & & & $\begin{array}{l}\text { mainly in } \\
\text { French }\end{array}$ \\
\hline France & French & Les Etudes Social & - & 1881- & $\begin{array}{l}----- \text { Still in } \\
\text { French }\end{array}$ \\
\hline France & French & Histoire, économie et société & - & $1908-$ & $\begin{array}{l}\text {----- Still in } \\
\text { French }\end{array}$ \\
\hline France & French & $\begin{array}{l}\text { Annales d'histoire économique et } \\
\text { sociale }\end{array}$ & - & 1929- & $\begin{array}{l}\text {----- Still in } \\
\text { French }\end{array}$ \\
\hline France & French & Économie appliquée & & 1948- & $\begin{array}{l}\text {----- Still } \\
\text { mainly in } \\
\text { French }\end{array}$ \\
\hline France & French & Revue économique & & $1950-$ & $\begin{array}{l}\text {----- Still } \\
\text { mainly in } \\
\text { French }\end{array}$ \\
\hline France & French & Economies et sociétés & - & $1967-$ & $\begin{array}{l}\text {----- Still in } \\
\text { French }\end{array}$ \\
\hline France & French & Cahiers d'économie politique & - & 1974- & $\begin{array}{l}\text {---- Still mix of } \\
\text { French and } \\
\text { English } \\
\text { language }\end{array}$ \\
\hline Germany & German & $\begin{array}{l}\text { Zeitschrift für die gesamte } \\
\text { Staatswissenschaft }\end{array}$ & $\begin{array}{l}\text { Journal of Institutional } \\
\text { and Theoretical } \\
\text { Economics JITE }\end{array}$ & 1844- & 1993 \\
\hline
\end{tabular}




\begin{tabular}{|c|c|c|c|c|c|}
\hline Germany & German & $\begin{array}{l}\text { Jahrbücher für Nationalökonomie } \\
\text { und Statistik }\end{array}$ & - & $1863-$ & German \\
\hline Germany & German & Schmollers Jahrbuch & $\begin{array}{l}\text { Journal of Applied } \\
\text { Social Science } \\
\text { Studies }\end{array}$ & 1871 & $\begin{array}{l}\text {----- Still partly } \\
\text { in German }\end{array}$ \\
\hline Germany & German & $\begin{array}{l}\text { Die Neue Zeit: Revue des geistigen } \\
\text { und öffentlichen Lebens }\end{array}$ & - & $1883-1923$ & ----- \\
\hline Germany & German & $\begin{array}{l}\text { Archiv fur Sozialwissenschaft und } \\
\text { Sozialpolitik }\end{array}$ & - & $1888-1933$ & ----- \\
\hline Germany & German & Weltwirtschaftliches Archiv & $\begin{array}{l}\text { Review of World } \\
\text { Economics }\end{array}$ & $1913-$ & 1995 \\
\hline Germany & German & Kredit und Kapital & - & $1968-$ & German \\
\hline Italy & Italian & $\begin{array}{l}\text { Giornale degli Economisti e Annali } \\
\text { di Economia }\end{array}$ & - & 1875 & 2000 \\
\hline Italy & English & $\begin{array}{l}\text { Banca nazionale del lavoro } \\
\text { quarterly review }\end{array}$ & $\begin{array}{l}\text { Previously: Quarterly } \\
\text { review. Banca } \\
\text { nazionale del lavoro; } \\
\text { Nowadays: BNL } \\
\text { Quarterly Review }\end{array}$ & $1947-$ & 1947 \\
\hline Italy & Italian & Ricerche Economiche & $\begin{array}{l}\text { Research in } \\
\text { Economics }\end{array}$ & $1947-$ & 1993 \\
\hline Italy & Italian & Economia internazionale & - & 1948- & 2001 \\
\hline
\end{tabular}




\begin{tabular}{|c|c|c|c|c|c|}
\hline Netherlands & Dutch & De Economist & $\begin{array}{l}\text { De Economist } \\
\text { Netherlands } \\
\text { Economic Review }\end{array}$ & $1852-$ & 1983 \\
\hline Norway & Norwegian & Norsk Økonomisk Tidsskrift & - & $1887-$ & $\begin{array}{l}\text {----- Still in } \\
\text { Norwegian }\end{array}$ \\
\hline Soviet Union & $\begin{array}{l}\text { English } \\
\text { translations }\end{array}$ & Problems of Economic Transition & - & $1958-$ & 1958 \\
\hline Soviet Union & $\begin{array}{l}\text { English } \\
\text { translations }\end{array}$ & Matekon & - & 1964-1998 & 1964 \\
\hline Spain & Spanish & Revista Española de Economía & $\begin{array}{l}\text { Spanish Economic } \\
\text { Review }\end{array}$ & 1971- & 1999 \\
\hline Spain & Spanish & Revista de Historia Económica & $\begin{array}{l}\text { Journal of Iberian and } \\
\text { Latin American } \\
\text { Economic History }\end{array}$ & 1945- & $\begin{array}{l}\text { Submissions in } \\
\text { English, } \\
\text { Spanish or } \\
\text { Portuguese }\end{array}$ \\
\hline Sweden & Swedish & $\begin{array}{l}\text { Statsvetenskaplig tidskrift för politik- } \\
\text { statistik-ekonomi }\end{array}$ & - & 1897-1963 & ----- \\
\hline Sweden & Swedish & Ekonomisk Tidskrift & Scandinavian Journal & 1899- & 1964 \\
\hline
\end{tabular}




\begin{tabular}{|c|c|c|c|c|c|}
\hline & & & of Economics & & \\
\hline Switzerland & German & Kyklos & $\begin{array}{l}\text { Kyklos International } \\
\text { Review for Social } \\
\text { Sciences }\end{array}$ & 1947- & 1993 \\
\hline Switzerland & French & Revue Économique et Sociale & - & 1943- & |----- \\
\hline
\end{tabular}

Sources:

Fonseca, Periodicals Service Company \& Schmidt Periodicals GmbH, home pages of journals, national libraries, econlit, etc

Notes:

Continental European Journals selected from 1850 onwards (emergence of academic economics journals, excl. light and news oriented journals,

or journals not principally dedicated to economics). Only journals that were founded until 1990 have been included.

\section{English language journals (only English speaking countries)}

\begin{tabular}{l|lc}
\hline Country & National journal name & Publishing \\
& & years \\
\hline Australia & Economic Record & $1924-$ \\
Australia & Australian Economic Papers & $1962-$ \\
Britain & Macmillan's Magazine & $1859-1907$ \\
Britain & Economic Journal & 1891 \\
Britain & Economic Review & $1891-1914$ \\
Britain & Economica & $1921-$
\end{tabular}




\begin{tabular}{|c|c|}
\hline Britain & Economic History Review \\
\hline Britain & The Manchester School of Economic and Social Studies \\
\hline Britain & Lloyds Bank Review \\
\hline Britain & Review of Economic Studies \\
\hline Britain & Oxford Economic Papers \\
\hline Britain & Scottish Journal of Political Economy \\
\hline Britain & Journal of Development Studies \\
\hline Britain & Cambridge Journal of Economics \\
\hline Canada & Canadian Journal of Economics* \\
\hline International & International Labour Review \\
\hline International & Econometrica \\
\hline International & Metroeconomica \\
\hline International & Journal of Industrial Economics \\
\hline International & IMF Staff Papers \\
\hline International & International Economic Review \\
\hline International & Journal of Economic Theory \\
\hline International & History of Political Economy \\
\hline International & Journal of International Economics \\
\hline International & International Journal of Game Theory \\
\hline International & Journal of Public Economics \\
\hline International & Journal of Monetary Economics \\
\hline International & Journal of Econometrics \\
\hline International & Atlantic Economic Journal \\
\hline
\end{tabular}

1927-

1929-

1930-

1933-

1938-

1953-

1964-

1977-

1935-

1921-

1933-

1949-

$1952-$

1954-

1960-

1969-

1969-

1971-

1971-

1972-

$1972-$

1973-

1973- 


\begin{tabular}{|c|c|}
\hline International & Journal of Mathematical Economics \\
\hline International & Journal of Development Economics \\
\hline International & Economics Letters \\
\hline International & Journal of Economic Dynamics and Control \\
\hline International & Journal of Economic Behavior and Organization \\
\hline International & Mathematical Social Sciences \\
\hline International & The New Palgrave: A dictionary of economics \\
\hline International & Review of Austrian Economics \\
\hline International & Economic Systems Research \\
\hline International & Games and Economic Behavior \\
\hline International & Structural Change and Economic Dynamics \\
\hline International & Journal of Evolutionary Economics \\
\hline South Africa & South African Journal of Economics \\
\hline US & Quarterly Journal of Economics \\
\hline US & Journal of American Statistical Association \\
\hline US & Journal of Political Economy \\
\hline US & Bulletin of the American Economic Association $\star *$ \\
\hline US & American Economic Review \\
\hline US & Review of Economics and Statistics \\
\hline US & Journal of Business \\
\hline US & Southern Economic Journal \\
\hline US & Encyclopedia of the Social Sciences \\
\hline US & Journal of Economic History \\
\hline
\end{tabular}


American Journal of Economics and Sociology

Review of Social Economy

Journal of Finance 1946-

International Organization 1947 -

Monthly Review 1948-

Economic Development and Cultural Change 1952-

Journal of Law and Economics 1958-

Western Economic Journal 1962-

Journal of Economic Issues

Journal of Economic Literature 1969-

Review of Radical Political Economy

Journal of Money, Credit and Banking 1969-

Brookings Papers on Economic Activity 1970-

Bell Journal of Economics ${ }^{\star \star *} \quad 1970-1973$

Carnegie-Rochester Conference Series on Public Policy 1973-

RAND Journal of Economics 1974-

Eastern Economic Journal

Journal of Post Keynesian Economics 1978-

Journal of Economic Perspectives 1987-

Review of Political Economy 1989-

* Formerly published as Canadian Journal of Economics and Political Science

** Predecessor of American Economic Review

*** Predecessor of RAND Journal of Economics

Sources: 
Fonseca, Periodicals Service Company \& Schmidt Periodicals $\mathrm{GmbH}$, home pages of journals, national libraries, econlit, etc Notes:

Continental European Journals selected from 1850 onwards (emergence of academic economics journals, excl. light and news oriented journals, or journals not principally dedicated to economics). Only journals that were founded until 1990 have been included. 